\title{
TISSUE ENGINEERING OF THE HUMAN CORNEA USING EX VIVO METHODS
}

\author{
Dóra Júlia Szabó, M.D.
}

Supervised by:

Prof. Dr. Goran Petrovski

M.D., Ph.D., med. Habil.

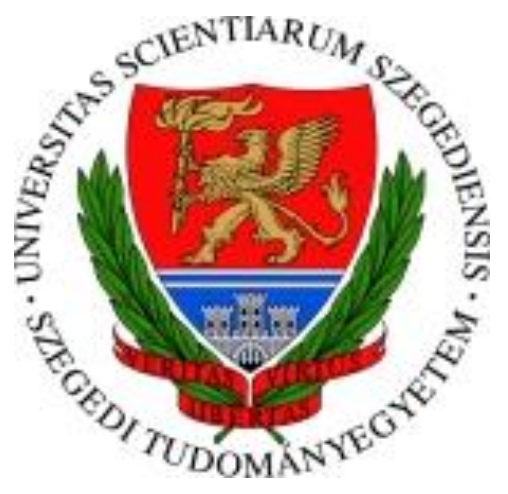

UNIVERSITY OF SZEGED

DEPARTMENT OF OPHTHALMOLOGY

DOCTORAL SCHOOL OF CLINICAL MEDICINE

SZEGED, 2018 


\section{List of publications}

This thesis is built upon the following publications:

I. Szabó DJ, Noer A, Nagymihály R, Josifovska N, Andjelic S, Veréb Z, Facskó A, Moe MC, Petrovski G.Long-Term Cultures of Human Cornea Limbal Explants Form 3D Structures Ex Vivo - Implications for Tissue Engineering and Clinical Applications. PLoS One. 2015 Nov 18;10(11):e0143053. PMID: 26580800

IF (2015): 3.057

II. Dóra Júlia Szabó, Richárd Nagymihály, Zoltán Veréb, Natasha Josifovska, Agate Noer, Petra Liskova, Andrea Facskó, Morten C. Moe, Goran Petrovski. Ex vivo 3D human corneal stroma model for Schnyder corneal dystrophy - role of autophagy in its pathogenesis and resolution. Histology and Histopathology, 2018 May;33(5):455-462. doi: 10.14670/HH-11-928. Epub 2017 Sep 5. PMID: 28872183

IF (2017): 2.025

\section{List of publications not related to this thesis:}

I. Enikő Balogh, Andrea Tóth, Emese Tolnai, Tímea Bodó, Dóra Júlia Szabó, Goran Petrovski, Viktória Jeney. Osteogenic differentiation of human lens epithelial cells might contribute to lens calcification. Biochim Biophys Acta. 2016 Sep;1862(9):1724-31. PMID: 27318027

IF (2016): 5.476 
II. Dóra Júlia Eszes, Dóra Júlia Szabó, Greg Russel, Phil Kirby, Edit Paulik, László Nagymajtényi, Andrea Facskó, Morten C. Moe, Beata Eva Petrovski. Diabetic retinopathy screening using telemedicine tools - pilot study in Hungary. Journal of Diabetes Research, vol. 2016, Article ID 4529824, 9 pages, 2016. doi:10.1155/2016/4529824

IF (2016): 2.717

III. Maria Hytti, Dora Szabo, Niina Piippo, Eveliina Korhonen, Paavo Honkakoski, Kai Kaarniranta, Goran Petrovski, Anu Kauppinen. Two dietary polyphenols, fisetin and luteolin, reduce inflammation but augment DNA damage-induced toxicity in human RPE cells. J Nutr Biochem. 2017 Apr;42:37-42. doi: 10.1016/j.jnutbio.2016.12.014. Epub 2017 Jan 9.PMID: 28113103

\section{IF (2016): 4.518}

IV. Josifovska N, Szabó DJ, Nagymihály R, Veréb Z, Facskó A, Eriksen K, Moe MC, Petrovski G. Cultivation and characterization of pterygium as an ex vivo study model for disease and therapy. Cont Lens Anterior Eye. 2017 Oct;40(5):283-292. doi: 10.1016/j.clae.2017.04.002. Epub 2017 May 24. PMID: 28550976

\section{IF (2016): 1.783}

V. Dóra Júlia Szabó, Marika Tóth, Zoltán Doró, Richárd Nagymihály, Natasha Josifovska, Andrea Facskó, Goran Petrovski. Cell death, clearance and inflammation: molecular crossroads and gene polymorphisms in the pathogenesis of age-related macular degeneration. Journal of Biochemical and Pharmacological Research 2:(3) pp. 132-143, 2014

\section{IF of publications related to the thesis: $\mathbf{5 . 0 8 2}$}

IF of all publications: 14.494 


\section{Table of Contents}

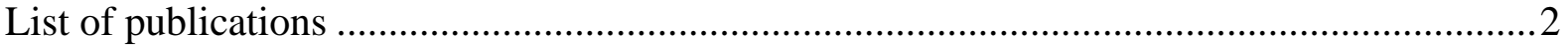

This thesis is built upon the following publications: ....................................................

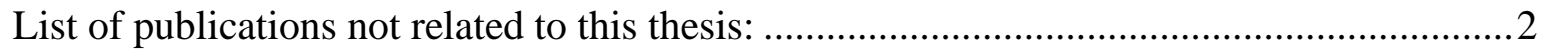

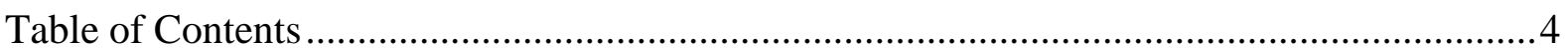

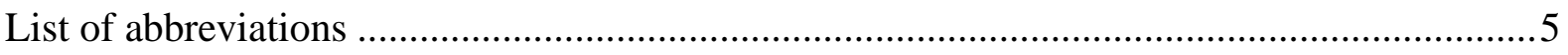

1. Magyar nyelvü összefoglaló (Summary in Hungarian) ..............................................

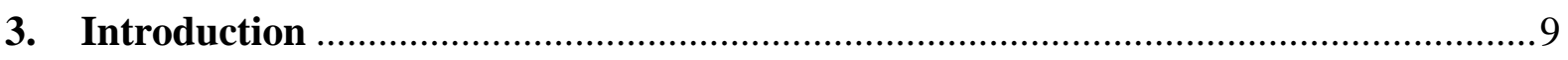

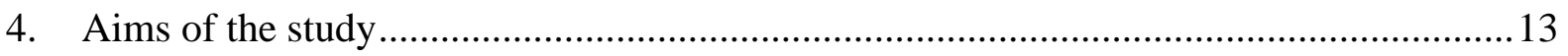

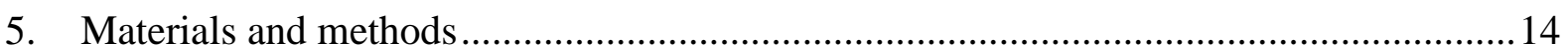

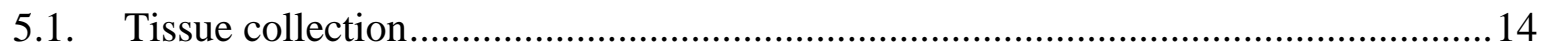

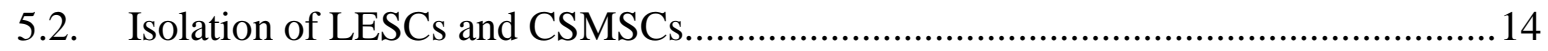

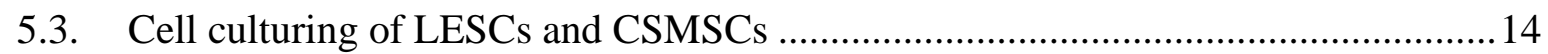

5.4. Treatment of long-term CSMSC cultures ...................................................... 15

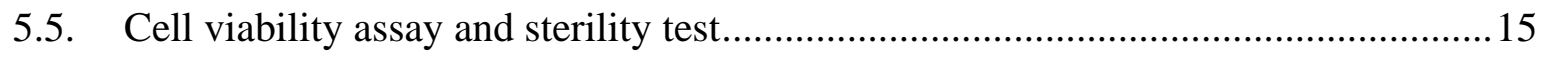

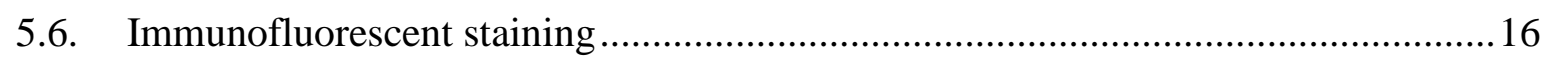

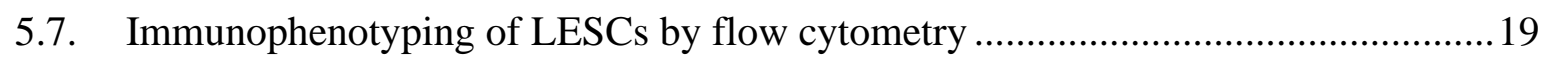

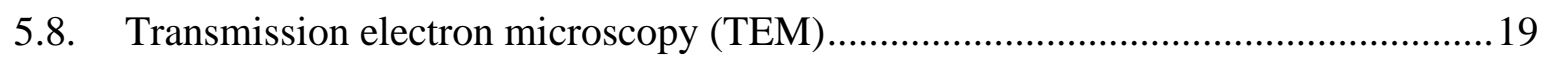

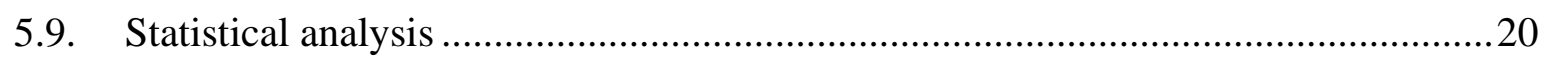

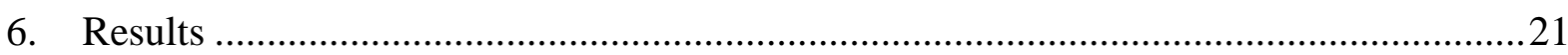

6.1. Tissue engineering of the human cornea limbal epithelial stem cells.....................21

6.2. Tissue engineering of the human corneal stroma - 3D model for Schnyder corneal

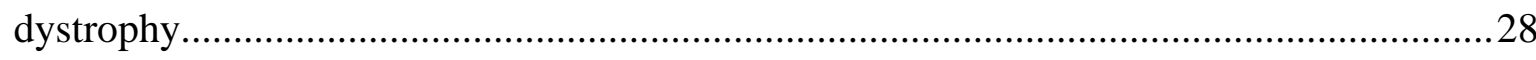

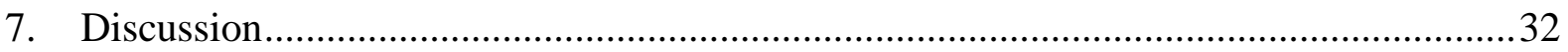

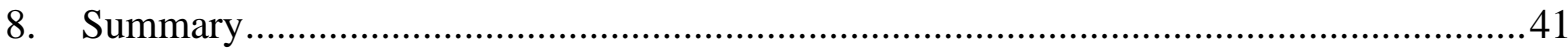

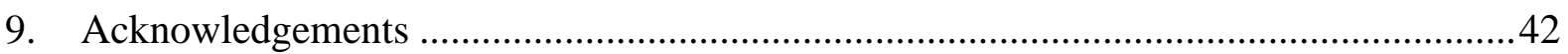

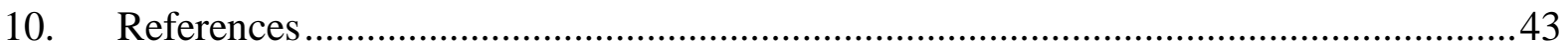




\section{List of abbreviations}

3D

3-MA

ABCG2

APC

ATP

Avs

$\mathrm{CD}$

CD117/ c-kit

CD144/VE-cadherin

CD146/MCAM

CD166/ALCAM

CD31/ PECAM

CD34

CD44/ H-CAM

CD47/ IAP

CD90/Thy-1

CK

CLET

CXCR4

CSMSCs

DALK

DAPI

DMEM

ECM

EDTA

FACS three dimensional

3-methyladenine

ATP-binding cassette sub-family G member 2 (CD338)

allophycocyanin

adenosine triphosphate

autophagic vacuoles

cluster of differentiation

c-kit

vascular endothelial-cadherin

melanoma cell adhesion molecule

activated leukocyte cell adhesion molecule

platelet endothelial cell adhesion molecule

cluster of differentiation 34 (a cell surface protein on hematopoietic stem cells).

homing-associated cell adhesion molecule

integrin-associated protein

thymocyte differentiation antigen 1

cytokeratin

cultured limbal epithelial cell therapy

chemokine receptor CXCR4

corneal stroma-derived mesenchymal stem-like cells

deep anterior lamellar keratoplasty

4',6-diamidino-2-phenylindole

Dulbecco modified Eagle's medium

extracellular matrix

ethylenediaminetetraacetic acid

fluorescence activated cell sorter 
FCS

FITC

HAM

hCSSCs

HLA-DR

LC3

LESC

LESCD

MLB

mTOR

p62/SQSTM1

p63

PBS

PE

PFA

PI3K

PK

PTK

RAP

SCD

SD

SEM

SP

TAC

TEM

UBIAD1

Vim

WT fetal calf serum

fluorescein-5-isothiocyanate

human amniotic membrane

human corneal stromal stem cells

human leukocyte antigen DR

microtubule-associated protein 1 light chain 3

limbal epithelial stem cell

LESC deficiency

multilamellar body

the mammalian target of rapamycin

sequestosome 1

tumor protein 63

phosphate buffered saline

phycoerythrin

paraformaldehyde

class III phosphatidyl inositol 3 kinase

penetrating keratoplasty

phototherapeutic keratectomy

rapamycin

Schnyder corneal dystrophy

standard deviation

standard error of measurement

side population

transient amplifying cell

transmission electron microscopy

UbiA Prenyltransferase Domain Containing 1

vimentin

wild type 


\section{Magyar nyelvü összefoglaló (Summary in Hungarian)}

A corneából származó felnőtt szöveti őssejtek alkalmazása a regeneratív medicinában, illetve az őssejtekkel létrehozott betegségmodellekben nagy lehetőségeket rejt magában.

Ex vivo tenyésztett limbális epitheliális őssejtek (LESC) átültetésével már most is sikeresen kezelhető a LESC deficiencia (LESCD). Munkánk során LESC-k hosszú távú tenyésztésével létrehozott sejtkultúrák karakterizálását végeztük el, mely jövőbeni szöveti tervezésre (tissue engineering) és klinikai alkalmazásra használható fel. A limbális szöveti explantátumból származó szövetkultúrákat több mint 3 hónapon át tenyészettük, melynek során nem használtunk scaffoldot ill. médiumunk tápanyag-kiegészítőforrásként csupán szérumot tartalmazott. A tenyésztés során 4 héten belül viábilis sejtek kinövése volt megfigyelhető az explantátumból. Immunfluoreszcens festéssel putatív őssejt markereket (ABCG2, CK15, CK19 és Vimentin), proliferációs markereket (p63a, Ki-67), a limbusban bazálisan elhelyezkedő epithelium sejtekre (CK8/18), illetve a differenciált cornea epithelium sejtekre (CK3 és CK12) jellemző markereket vizsgáltuk. Morfológiai és immunfestés vizsgálatok eredményei kimutatták, hogy hosszú távú tenyésztés során a kinövő sejtek többrétegü, térbeli szerkezetet hoztak létre, melyben ECM anyagok szabályos jellegü depozíciója volt megfigyelhető (I-es, IV-es és V-ös típusú kollagén). A LESC-k erős p63a, ABCG2 kifejeződés mutattak, jellegzetes felszíni mintázatuk, "ujjlenyomatuk" (CD117/c-kit, CXCR4, CD146/MCAM, CD166/ALCAM) expressziója a rövid távú sejtkultúrákhoz viszonyítva változott. Összefoglalásképpen elmondható, hogy LESC-k hosszú távú tenyésztésével létrehoztunk egy olyan őssejtben gazdag, háromdimenziós sejtkultúrát, mely alkalmas lehet mint további kutatási, mint klinikai transzplantációs célokra.

A multilamelláris testek (MLB-k) cytoplasmában található koncentikus elrendeződésű memránokból állnak, képződésük az autofágia folyamatához kötött. A corneában ezen elváltozások megjelenése Schnyder-féle cornea disztrófiában (SCD) jellemző, mely a szaruhártya strómát érintő, transzparencia csökkenéssel járó, ritka, progresszív lefolyású betegség. Tanulmányunkban cornea stróma eredetü mesenchymális őssejt-szerü sejtek (CSMSC-k) hosszú távú tenyésztésével a szaruhártya ex vivo háromdimenziós stróma modelljét és az SCD modelljét hoztuk létre. A CSMSC-k izolálása a cornea centrális részéből történt, amit több mint 3 hónapos tenyésztés követett, melynek során a sejtek spontán háromdimenziós szerkezetet alkottak. AZ MLB-k jelenlétét a szövetben elektronmikroszkóppal, az autofágia markereit (p62, LC3) pedig immunfestéssel vizsgáltuk. 
Autofágia indukálására klasszikus szérum megvonást, illetve rapamyin kezelést végeztünk, gátlására 3-metiladenint alkalmaztunk 24 órán át. A CSMSC-k 3-4 hét elteltével spontán háromdimenziós szerkezet létrehozására képesek, melyet saját maguk által termelt I-es típusú kollagént tartalmazó ECM vesz körül. Az elektronmikroszkópos vizsgálatok bebizonyították az MLB-k meglétét a hosszú távú (>3 hónap) tenyészetekben. Szérum megvonásos, illetve rapamyin kezelés hatására számuk növekedését, 3-metiladeninnel végzett autofágia inhibíciót követően mennyiségük csökkenését figyeltük meg. Az LC3 és p62 expressziójának változása a különböző kezelések hatására alátámasztotta az autofágia szerepét a folyamatban. A CSMSC-kben hosszú távú tenyésztés hatására kialakuló MLB képződés a jövőben a cornea stróma betegségek (beleértve az SCD) potenciális ex vivo modelljeként szolgálhatna. Az autofágia gátlásával elért MLB képződés csökkentése újfajta eljárások kifejlesztéséhez vezethet a betegség kezelésében.

Mindkét tanulmányunk hozzájárul a szaruhártya háromdimenziós szövettenyésztésének, illetve ezek jövőbeni klinikai alkalmazásának fejlesztéséhez. 


\section{Introduction}

The cornea is the clear, curved, anterior part of the eye that provides two-thirds of its focusing power and along with the sclera acts as an external protection for the eye. It is formed from the neural crest during the end of the eye's organogenesis and has a rather complex structure that enables the cornea to be perfectly transparent [1]. The cornea has a lamellar structure consisting of 5 layers (from anterior to posterior): corneal epithelium, Bowman's layer, stroma, Descemet's membrane and corneal endothelium [2].

The most superficial part consists of 4-5 layers of non-keratinized squamous epithelium connected by tight junctions and a monolayer of basal cells that form a protective, impermeable barrier. The renewal of the epithelium is continuous: the outermost cells lost by desquamation are replaced by cells moving centripetally and towards the surface originated from the limbal basal epithelium. The limbus is an approximately $1.5-2 \mathrm{~mm}$ wide rim located at the corneo-scleral junction. It contains the limbal epithelial crypts, where limbal epithelial stem cells (LESCs) reside in a specific and highly regulated microenvironment, the niche [35]. LESCs are unipotent stem cells that maintain a relatively undifferentiated state in the niche, but have a high proliferative potential and can undergo asymmetric division generating a stem cell that remains in the niche and a transient amplifying cell (TAC). The TACs proliferate in the basal layer of the limbus and migrate towards the surface and centripetally, progressively becoming more differentiated until they loose their proliferation ability and become mature central epithelial cells (CECs) [6]. Unfortunately, at present, there is no definitive marker for identifying LESCs, but there are combinations of markers whose presence or absence can be used to help distinguish them from other cell types [7].

LESCs are important not only in the maintenance of the normal corneal epithelial homeostasis, but also in epithelial repair in case of injury. When large epithelial wounds occur, activated limbal stem cells are recruited to regenerate the corneal surface, a process that is mediated by environmental factors as well. After corneal injury with small wounds, healing may be achieved within 12 hours by CECs [8].

Decreased number of stem cells or disturbances in the stem cell microenvironment due to injury, such as chemical or thermal burns or disease like Stevens-Johnson syndrome, can cause painful epithelial defects, stromal scarring, corneal neovascularization, conjunctivalization that results in impaired vision and ultimately vision loss. LESC deficiency (LESCD) treatment depends on the severity of the disese: milder cases can be 
treated by conservative methods (corneal scraping, amniotic membrane patching), but in more severe cases, when there is not enough LECSs left, invasive methods may be needed.

One treatment option is the replacement of the stem cell population by grafting limbal biopsies from the patient's healthy eye or using allografts from donors [9]. Allogeneic transplantation is restricted by the lack of donor tissues and the need for immunosuppression. The use of autogenic grafts have good results without the requirement of systemic immunosuppressive treatment, but taking large grafts from the patient's fellow/healthy eye carries the risk of inducing LESCD in that eye and it is not even possible in bilateral cases. To avoid this, an ex vivo expansion of small biopsies from the patient, a patient's relative or cadavers has been developed [10].

In case of cultured limbal epithelial cell therapy (CLET), the cultivation of LESCs is usually supported by different synthetic or biological scaffolds that assist the formation of cell sheets, which are then transferred to the affected eyes. The most widely used carrier is human amniotic membrane (HAM), as it is an avascular tissue that possesses anti-inflammatory and anti-angiogenic properties. Other carriers include collagen I, fibrin, siloxane hydrogel contact lenses, polymethacrylate, poly( $\varepsilon$-caprolactone), chitosan-Gelatin, Silk Fibroin, human anterior lens capsule and the like $[11,12]$. Co-cultivation of LESCs on feeder layers is also a common culturing method, using inactivated murine $3 \mathrm{~T} 3$ fibroblasts. The components of the cell culture medium also vary in the presence or absence of animal serum or other growth supplements. Any use of xenogenic components poses a risk of transfer of foreign agents to the recipient. There is a difference in the results of corneal stem cell transplantations depending whether it is a direct graft or expanded cultures [13-15]. The post transplantational survival rate of the recovered grafted donor cells also varies [16].

Besides LESCs, use of non-ocular cells such as embryonic stem cells, bone-marrow derived stem cells, dental-pulp stem cells and oral mucosal cells, have been attempted for treatment of LESCD [11]. Despite intense research in this field, in the last couple of years, the real characteristics of long-term ex vivo expanded LESCs have not been investigated.

The human cornea is approximately $540 \mu \mathrm{m}$ thick and the stroma involves $90 \%$ of its thickness. The stroma is separated from the epithelium by the acellular Bowman's layer made of collagen and by the Descemet's membrane from the side of the corneal endothelium. The epithelium and endothelium play important roles in maintaining the optimal corneal hydration, and therefore the transparency of the cornea by creating an impermeable barrier to 
fluid diffusion anteriorly and by actively removing excess fluid posteriorly by the endothelial pump function. The stroma's main component is water and collagen rich extracellular matrix (ECM), mainly type I and type $\mathrm{V}$ collagen organized into lamellae, but it also contains proteoglycans, glycoproteins and inorganic salts. The uniformly spaced lamellar structure maintains the transparency of the cornea. It contains resting stromal keratocytes that are mesencyhmal-derived altered fibroblasts dispersed between the collagen layers with long, thin cytoplasmatic processes creating a communicating three dimensional (3D) network. The main function of the keratocytes under normal circumstances is to maintain the ECM structure by continuously producing its elements and also degrading it by enzymes secreted [17]. In case of corneal injury, the keratocytes transform into fibroblasts and take part in the corneal healing process. Besides keratocytes, immune cells and corneal stroma derived mesenchymal stem-like cells (CSMSC) also reside in the stroma.

CSMSCs are multipotent stem cells located in the central corneal stroma that have a potential to differentiate in vitro into fat, bone and cartilage, but also keratocytes and neural cells [18]. They possess some immunosuppressive features, suggesting that they can play an important role in immune regulation of the surrounding microenvironment and regeneration of corneal stroma and epithelium $[19,20]$. It has been shown that CSMSCs express important markers of MSCs such as CD73, CD90, CD105 and CD140b/PDGFR $\beta$, but are negative for CD34, CD45, CD133, and HLA-DR, which are markers of hematopoietic lineage or activated cells.

Schnyder corneal dystrophy ((SCD); previously known as Schnyder crystalline corneal dystrophy) is a rare type of corneal disease that appears bilaterally as a subepithelial opacification under the Bowman's layer [21]. The onset is usually in the $2^{\text {nd }}$ or $3^{\text {rd }}$ decade, starting with a central haze, which by the $5^{\text {th }}$ decade affects the whole corneal surface. The corneal opacity is caused by abnormal deposition of intracellular and extracellular esterified and unesterified phospholipids and cholesterol in the stroma, later affecting the Bowman's layer as well. The word crystalline in the earlier name of the condition refers to the yellowwhite needle-shaped deposits that were considered necessary for the diagnosis, but it has been proved that only about $50 \%$ of the patients develop crystals, hence the change in the terminology. Although SCD is a progressive disease, the clinical severity varies among different individuals. The condition is hereditary, and it is linked to the UbiA Prenyltransferase Domain Containing 1 (UBIAD1) gene located on chromosome 1 (1p36.3). Currently, there is no treatment available to stop or slow down the progression, therefore the clinical management of SCD involves invasive procedures such as phototherapeutic 
keratectomy (PTK), penetrating keratoplasty (PK) or deep anterior lamellar keratoplasty (DALK) [22, 23].

Electron microscopic examintation shows multilamellar bodies (MLBs) in the stroma of the affected corneas. MLB formation is associated with a presence of excess lipid. The latter are round shaped vesicules with 100-2400 $\mu \mathrm{m}$ diameter, and an ultrastructure consisting of multiple, concentric electron dense lamellae rich in lipoprotein. While the lipids can appear in physiological conditions, such as the storage and secretion of surfactant in type II pneumocytes, their appearance is also notable in some pathological changes (e.g. lysosomal storage diseases, like gangliosidosis, Tay-Sachs, Fabry and Niemann-Pick disease). The process of MLB formation is proved to be an autophagy dependent mechanism [24]. Autophagy is the controlled degradation of sequestered cytoplasmic components by lysosomal hydrolytic enzymes. It is essential in maintaining the cellular homeostasis. Under stress conditions autophagy is upregulated to protect the cell from potential damage. The lysosomal nature of autophagic vacuoles (AVs) and MLBs indicate a similar pathway in their formation. In general, autophagy can be stimulated by starvation and rapamycin (via the mammalian target of rapamycin (mTOR) pathway), and inhibited by 3-methyladenine (3MA) - an inhibitor of the class III phosphatidyl inositol 3 kinase (PI3K) [25]. 


\section{Aims of the study}

1. To isolate and long-term cultivate cornea LESCs in media containing serum as the only growth supplement without the use of scaffolds or special surface treatment.

2. To characterize the long-term ex vivo expanded LESCs by morphological (lightmicroscopy, TEM) and molecular biology techniques (immunofluorescent staining, flow-cytometry, cell viability test).

3. To compare the expression of the long-term ex vivo cultured LESCs surface markers to the results previously obtained from short-term ex vivo cultured LESCs.

4. To isolate and long-term cultivate human corneal stroma-derived stem-like cells (CSMSCs) from the central cornea to induce MLB formation.

5. To investigate the effect autophagy has upon MLB formation in long-term expanded CSMSC cultures.

6. To examine the long-term CSMSC cultures as a possible model for studying Schynder corneal dystrophy (SCD). 


\section{Materials and methods}

\subsection{Tissue collection}

All tissue collection complied with the Guidelines of the Helsinki Declaration and was approved by the Regional Ethical Committee at the University of Debrecen, Hungary (DEOEC RKEB/IKEB 3094/2010 and 14415/2013/EKU-183/2013). Hungary follows the EU Member States' Directive 2004/23/EC on presumed consent practice for tissue collection. Limbal and corneal tissue collection was done within 24 hours of biologic death from cadavers. Before enucleation, the bulbus was thoroughly washed with $5 \%$ povidone iodine (Betadine; Egis, Budapest Hungary) and rinsed in phosphate buffered saline (PBS). The conjunctiva was lifted, incised and separated from the limbal junction in 360 degrees with conjunctival scissors. Blunt dissection was performed to separate the Tenon capsule from the sclera before isolating and cutting the external muscles. The optic nerve was cut with enuclation scissors and the bulbus was placed in PBS.

\subsection{Isolation of LESCs and CSMSCs}

The isolation of the cells was performed under sterile conditions within 1 hour of enuclation. The bulbus was briefly immersed in povidoneiodide and rinsed in PBS. In case of LESC isolation, two concentric circles were incised superficially, marking the borders of the limbal area, and small $(2 \times 2 \times 0,25 \mathrm{~mm})$, rectangular-shaped tissues were dissected from the superficial layer using a lamellar knife placed tangential to the surface being cut. Multiple grafts were collected from a single eye, mainly from the superior, nasal and inferior parts of the corneo-scleral rim. In case of CSMSC isolation, the disinfection was followed by cutting out a corneal button using a lamellar knife. The epithelium with the Bowman's membrane and endothelium with the Descemet's membrane were scraped off with a surgical knife. The central part of the cornea stroma (approximately a 6-7 diameter cube) was then cut into multiple small pieces.[20, 26]

\subsection{Cell culturing of LESCs and CSMSCs}

LESC explants were plated into 24-well cell culture plates and viscoelastic material (ProVisc, Alcon, Fort Worth, TX, USA) was added on top of the tissues to support adherence. The cultures were maintained in $1 \mathrm{~mL}$ Dulbecco's Modified Eagle's Medium (DMEM, Sigma- 
Aldrich, St. Louis, MO, USA), supplemented with 10\% Fetal Calf Serum (FCS, SigmaAldrich, St. Louis, MO, USA), 200 mM/mL L-glutamine (Sigma-Aldrich, St. Louis, MO, USA), $1 \%$ Antibiotic/Antimycotic Solution (PAA, Pasching, Austria) at $37^{\circ} \mathrm{C}, 5 \% \mathrm{CO}_{2}$. The media was changed every alternate day for more than 3 months without passaging.

The corneal stroma explants were seeded into 24-well cell culture plates, cultivated in $1 \mathrm{~mL}$ low glucose DMEM (Sigma-Aldrich, St. Louis, MO, USA) supplemented with $10 \%$ fetal calf serum (FCS, Sigma-Aldrich) and 1\% Antibiotic/Antimycotic Solution (PAA, Pasching, Austria), at $37^{\circ} \mathrm{C}, 5 \% \mathrm{CO}_{2}$. The medium was changed on alternating days, and the cells were maintained at passage 0 .

The growth of the LESC and CSMSC cultures was monitored under phase contrast microscope on a regular basis.

\subsection{Treatment of long-term CSMSC cultures}

After long-term (> 3 months) expansion, the cultures were treated to test for presence of autophagy. Each treatment was performed on the same three donors, with the average age of the cultures being $239 \pm 130$ days $(n=3)$. Autophagy induction was carried out using $50 \mathrm{nM}$ rapamycin (RAP) (Sigma-Aldrich) treatment for 24 hours, and by starvation using serum free media, also for 24 hours. For the inhibition of autophagy, the cultures were treated with 10mM 3-MA (Sigma-Aldrich) for 24 hours. The cell cultures forming a membrane were then lifted and collected from the cell culture plates for further analysis.

\subsection{Cell viability assay and sterility test}

To assess cell viability of LESC cultures, CellTiter-Glo ${ }^{\circledR}$ luminescent cell viability assay and traditional trypan blue dye exclusion test was used. The CellTiter-Glo ${ }^{\circledR}$ (Promega, WI, USA) is a fluorescent assay with a single reagent for determining the metabolically active cells by quantifying the ATP level that is proportional to the viable cells present in the culture. We used altogether 4 samples from 3 donors. After trypsinization and centrifugation, the cells were suspended in $500 \mu \mathrm{L}$ fresh media containing serum and the same amount of CellTiter Glo Reagent was added to the cells. The samples were shaken for 2 minutes and incubated at room temperature for 10 minutes, then transfered to a 96-well plate. Reading the fluorescence intensity was done by a Luminoskan Ascent luminometer (Thermo Scientific, USA). The trypan blue (Sigma Aldrich, MO, USA) vital staining was performed by first trypsinizing the 
adherent cells, then adding to the cell suspension an equal amount of dye (50 $\mu \mathrm{L})$. The number of viable cells was estimated by using a hemocytometer (Burker chamber).

The long-term LESC cultures were regularly tested for absence of Mycoplasma contamination (Mycoalert PLUS Mycoplasma Detection Kit, Lonza, Cat. No.: LT07-710) by an accredited microbiology laboratory (University of Debrecen).

\subsection{Immunofluorescent staining}

The immunofluorescent staining for long-term LESC and CSMSC cultures were carried out according to stardard laboratory protocols. After peeling off the cultured tissues from the plate with forceps, the samples were fixed in $4 \%$ paraformaldehyde, followed by dehydration in graded series of alcohol and finally embedded in paraffin. Sectioning was performed using a rotary microtome and after mounting the 3-4 $\mu \mathrm{m}$ thick tissue sections onto histological slides, heat induced antigen retrieval, blocking and immunofluorescent labeling was performed. A 4',6-diamidino-2-phenylindole (DAPI) staining was used to visualize the nuclei. The LESC samples were characterized for markers of stemness (ABCG2, CK15, CK19, Vim), proliferation (p63 $\alpha$, Ki-67), limbal epithelial cells- (CK8/18) and differentiated corneal epithelial cell markers (CK3 and CK12) (details are shown in Table 1.).

The CSMSC tissues were investigated for autophagy and the effects of its induction or inhibition by microtubule-associated protein 1 light chain 3 (LC3) and p62 protein, also known as sequestosome 1 (SQSTM1) staining. The ECM deposition was examined by labeling for collagen I, IV and V (details are shown in Table 2.).

The visualisation and imaging of immunofluorescent staining was performed by a ZEISS Axio Observer. Z1 microscope (ZEISS, Oberkochen, Germany) and an EVOS FL microscope (Advanced Microscopy Group, Bothell, WA). For analyzing the images ImageJ software version 1.50 (National Institutes of Health, Bethesda, MD) was used.

\begin{tabular}{|c|c|c|c|c|c|}
\hline Antibody & Catalog No. & Company & Clonality & Antigen & Dilution \\
\hline ABCG2 & Sc-58222 & $\begin{array}{c}\text { Santa } \\
\text { Cruz }\end{array}$ & $\begin{array}{c}\text { Mouse } \\
\text { monoclonal }\end{array}$ & $\begin{array}{c}\text { AA 271-396 of } \\
\text { ABCG2 of human } \\
\text { origin }\end{array}$ & $1: 50$ \\
\hline CK3 & Sc-49179 & Santa & Goat & Peptide mapping at & $1: 50$ \\
\hline
\end{tabular}




\begin{tabular}{|c|c|c|c|c|c|}
\hline & & Cruz & polyclonal & $\begin{array}{c}\text { the C-terminus of } \\
\text { CK3 of human origin }\end{array}$ & \\
\hline $\begin{array}{l}\text { CK8 } \\
\text { CK18 }\end{array}$ & Ab17139 & Abcam & $\begin{array}{c}\text { Mouse } \\
\text { monoclonal }\end{array}$ & $\begin{array}{l}\text { Cytokeratins from the } \\
\text { human breast } \\
\text { carcinoma cell line } \\
\text { MCF-7 }\end{array}$ & $1: 50$ \\
\hline CK12 & Sc-17009 & $\begin{array}{l}\text { Santa } \\
\text { Cruz }\end{array}$ & $\begin{array}{c}\text { Goat } \\
\text { polyclonal }\end{array}$ & $\begin{array}{l}\text { Peptide mapping near } \\
\text { the C-terminus of } \\
\text { CK12 of human } \\
\text { origin }\end{array}$ & $1: 50$ \\
\hline CK15 & sc-47697 & $\begin{array}{l}\text { Santa } \\
\text { Cruz }\end{array}$ & $\begin{array}{c}\text { Mouse } \\
\text { monoclonal }\end{array}$ & $\begin{array}{c}\text { Last } 17 \text { amino acids } \\
\text { of Cytokeratin } 15 \text { of } \\
\text { human origin }\end{array}$ & $1: 300$ \\
\hline CK19 & Sc-33119 & $\begin{array}{l}\text { Santa } \\
\text { Cruz }\end{array}$ & $\begin{array}{c}\text { Goat } \\
\text { polyclonal }\end{array}$ & $\begin{array}{l}\text { Peptide mapping at } \\
\text { the N-terminus of } \\
\text { CK19 of human } \\
\text { origin }\end{array}$ & $1: 50$ \\
\hline Collagen I. & Ab34710 & Abcam & $\begin{array}{c}\text { Rabbit } \\
\text { polyclonal }\end{array}$ & $\begin{array}{l}\text { Human collagen I. } \\
\text { AA 1-1464 }\end{array}$ & $1: 200$ \\
\hline Collagen IV. & \#MS-747-S & $\begin{array}{l}\text { Thermo } \\
\text { Scientific }\end{array}$ & $\begin{array}{c}\text { Mouse } \\
\text { monoclonal }\end{array}$ & Human glomeruli & $1: 50$ \\
\hline Collagen V. & Ab7046 & Abcam & $\begin{array}{c}\text { Rabbit } \\
\text { polyclonal }\end{array}$ & $\begin{array}{l}\text { Full length native } \\
\text { protein (purified) } \\
\text { corresponding to } \\
\text { collagen V. AA 1- } \\
1745\end{array}$ & $1: 500$ \\
\hline $\mathrm{Ki}-67$ & \#RM-9106-S & $\begin{array}{l}\text { Thermo } \\
\text { Scientific }\end{array}$ & $\begin{array}{c}\text { Rabbit } \\
\text { monoclonal }\end{array}$ & $\begin{array}{c}\text { Synthetic peptide } \\
\text { derived from human } \\
\text { Ki-67 protein }\end{array}$ & $1: 200$ \\
\hline p63a & Sc-5301 & $\begin{array}{l}\text { Santa } \\
\text { Cruz }\end{array}$ & $\begin{array}{c}\text { Mouse } \\
\text { monoclonal }\end{array}$ & $\begin{array}{c}\text { AA 513-641 of } \\
\text { TA*p63a of human } \\
\text { origin }\end{array}$ & $1: 50$ \\
\hline
\end{tabular}




\begin{tabular}{|c|c|c|c|c|c|}
\hline Vimentin & \#RM9120-S & $\begin{array}{c}\text { Thermo } \\
\text { Scientific }\end{array}$ & $\begin{array}{c}\text { Rabbit } \\
\text { monoclonal }\end{array}$ & $\begin{array}{c}\text { Recombinant protein } \\
\text { encoding human } \\
\text { vimentin }\end{array}$ & $1: 200$ \\
\hline
\end{tabular}

Table 1. Summary of the antibodies used for immunohistochemistry in LESC cultures.

\begin{tabular}{|c|c|c|c|c|c|}
\hline Antibody & Catalog No. & Company & Clonality & Antigen & Dilution \\
\hline LC3 & NB100-2220 & $\begin{array}{c}\text { Novus } \\
\text { Biologicals }\end{array}$ & $\begin{array}{l}\text { Rabbit } \\
\text { polycl. }\end{array}$ & MAP1LC3B & $1: 200$ \\
\hline $\begin{array}{c}\text { p62 } \\
\text { (SQSTM1 } \\
\text { (D-3)) }\end{array}$ & Sc-28359 & Santa Cruz & $\begin{array}{l}\text { Mouse } \\
\text { monocl. }\end{array}$ & $\begin{array}{c}\text { amino acids } 151- \\
440 \text { of SQSTM1 of } \\
\text { human origin }\end{array}$ & $1: 200$ \\
\hline Collagen I. & Ab34710 & Abcam & $\begin{array}{l}\text { Rabbit } \\
\text { polycl. }\end{array}$ & $\begin{array}{l}\text { Human collagen I. } \\
\text { AA } 1-1464\end{array}$ & $1: 200$ \\
\hline Collagen IV. & \#MS-747-S & $\begin{array}{l}\text { Thermo } \\
\text { Scientific }\end{array}$ & $\begin{array}{c}\text { Mouse } \\
\text { monocle. }\end{array}$ & Human glomeruli & $1: 50$ \\
\hline Collagen V. & $\mathrm{Ab} 7046$ & Abcam & $\begin{array}{l}\text { Rabbit } \\
\text { polycl. }\end{array}$ & $\begin{array}{l}\text { Protein } \\
\text { corresponding to } \\
\text { coll. V. AA } 1-1745\end{array}$ & $1: 500$ \\
\hline
\end{tabular}

Table 2. Summary of the antibodies used for immunohistochemistry in CSMSC cultures. 
5.7. Immunophenotyping of LESCs by flow cytometry

The phenotype of the long-term cultured LESCs was determined by multicolor flow cytometry using FITC-, PE- and APC- conjugated antibodies against selected surface proteins: CD47,CD90/Thy-1, CD117/c-kit, CD146/MCAM, CD166/ALCAM, CXCR4 (all from R\&D Systems, Minneapolis, MN, USA) (details are shown in Table 3.).

Cells were washed with their growth medium and twice with a Fluorescence-Activated Cell Sorting (FACS) buffer after harvesting with $0.025 \%$ trypsin-EDTA. Samples were labeled for 30 minutes on ice, then washed again with FACS buffer and fixed in 1\% PFA/ PBS and analyzed within 1 day.

The samples were measured on a FACS Calibur flow cytometer (BD Biosciences Immunocytometry Systems) and the data were analyzed using Flowing Software 2.5 (PerttuTerho, Turku Centre for Biotechnology, University of Turku, Finland). For comparison, surface marker expression of short-term ( 2 weeks) cultivated LESCs that were isolated with the same method and cultured under the same conditions as long-term ones was used.

\begin{tabular}{|l|l|l|l|}
\hline Antibody & Clone & Catalog No. & Company \\
\hline CD34 & 581 & 555821 & BD Biosciences \\
\hline CD44 & BJ18 & 338804 & BD Biosciences \\
\hline CD90/Thy-1 & & 555595 & BD Biosciences \\
\hline CD31/PECAM & 9 G11 & FAB3567P & R\&D Systems \\
\hline CD47 & 472603 & FAB4670A & R\&D Systems \\
\hline CD117/c-kit & 47233 & FAB332P & R\&D Systems \\
\hline CD146/MCAM & 128018 & FAB932A & R\&D Systems \\
\hline CD166/ALCAM & 105902 & FAB6561P & R\&D Systems \\
\hline CXCR4 & 44717 & FAB173A & R\&D Systems \\
\hline
\end{tabular}

Table 3. List of antibodies used for FACS analysis

5.8. Transmission electron microscopy (TEM)

The ultrastructural analysis of the 3D long-term LESC and CSMSC cultures was performed by TEM. 
The LESC tissues were fixed overnight at $4^{\circ} \mathrm{C}$ in a freshly prepared fixative containing $2 \%$ glutaraldehyde in cacodylate buffer $(\mathrm{pH} 7,4)$.

The CSMSC tissues were fixed for 24 hours at room temperature in a freshly prepared fixative containing $2.5 \%$ glutaraldehyde and $4 \%$ paraformaldehyde in $0.2 \mathrm{M}$ cacodylate buffer. After fixation, the samples were washed in PBS (3x5 mins), and were kept in PBS at $4^{\circ} \mathrm{C}$ until further processing.

For both LESC and CSMSC cultures, 1\% osmium tetroxide was used for post-fixation, followed by dehydration in ascending ethanol series and immersion in propyleneoxide for 20 minutes. Finally the samples were embedded in Epon (Electron Microscopy Sciences, Hatfield, PA). For ultra thin sectioning (60-70 nm thick section), a Leica Ultracut Ultramicrotome UCT (Leica, Wetzlar, Germany) was used, followed by staining of the samples with uranyl acetate and lead citrate, then examined using a Tecnai 12 transmission electron microscope (Phillips, Amsterdam, the Netherlands).

\subsection{Statistical analysis}

The percentage of cells positive for a given marker was determined by counting the positive cells in a visual field with the help of nuclear staining by same three independent individuals. The results are expressed as mean \pm SD or SEM.

Each experiment was performed at least three times, and each sample was tested in triplicates. Statistically significant difference was determined with Student's t-test and a value of $\mathrm{p} \leq 0.05$ was considered significant. 


\section{Results}

\subsection{Tissue engineering of the human cornea limbal epithelial stem cells}

LESCs cultured ex vivo start growing out from the explants after 5-7 days as revealed by phase contrast microscopy, and form a monolayer within 2 weeks, to then produce a 3D multilayer structure. After long-term expansion, the stratified outgrowth forms a macroscopically visible, thick membrane that fills out the well of the cell culture plate that could be air-lifted by forceps.

Immunofluorescent staining of these sheets revealed a different distributional pattern of molecules and markers in the 3D cell outgrowth proximal to the explants versus distal to the explants.

From the markers expressed by differentiated corneal epithelium, CK3 and CK12, the former was negative in both proximal and distal to the explants, but the latter showed a mild positivity proximal to the explants $(18.1 \pm 1.6 \%)$, and an even weaker expression in the distal outgrowing cell sheets $(7.4 \pm 2.4 \%)$ (Fig. 1$)$. 

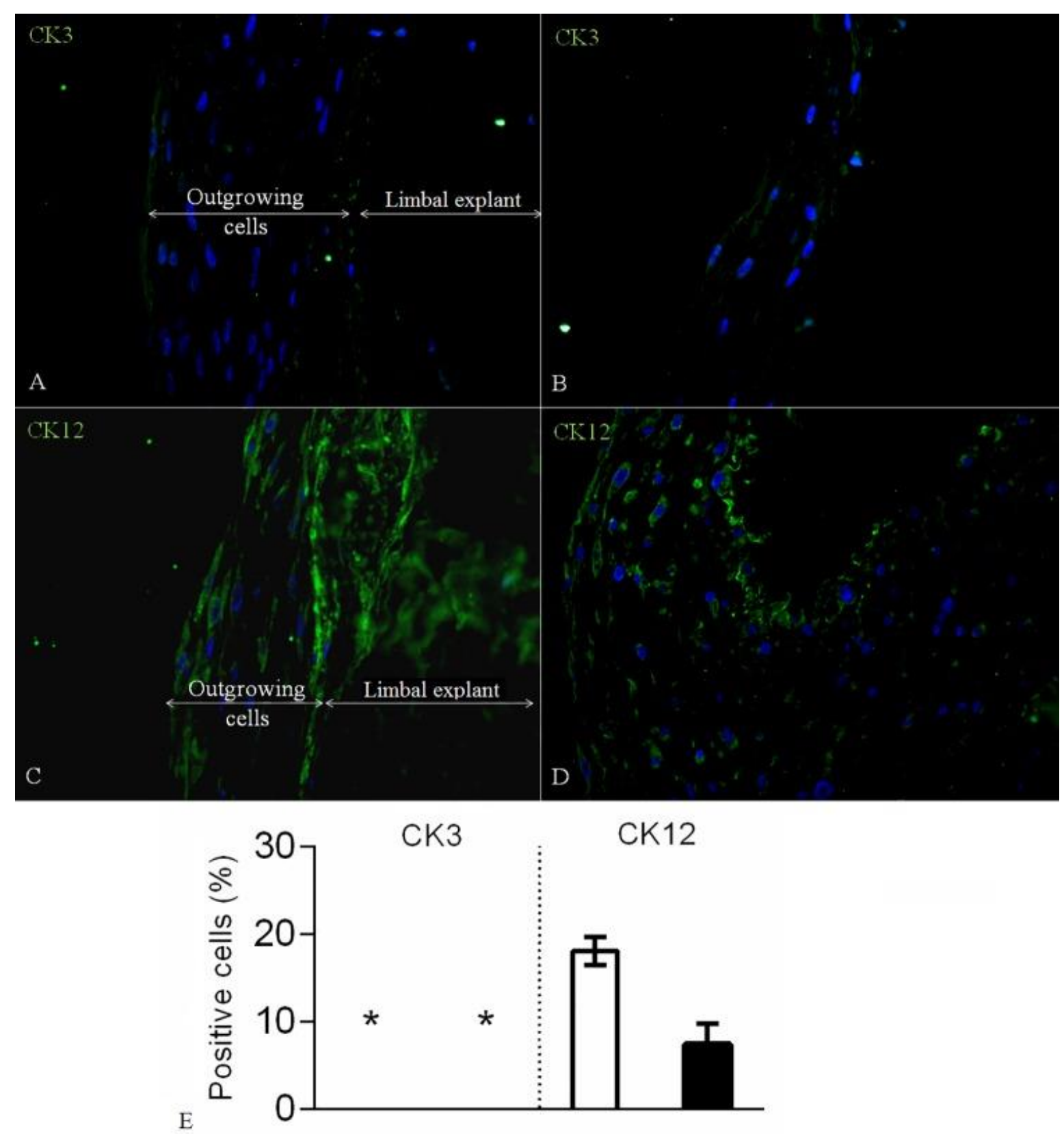

Figure 1. Limbal explants and 3D cell outgrowths stained for differentiation markers. Limbal explants and outgrowing cells proximal (A, C) and distal from it (B, D) are shown stained for CK3 and CK12, respectively (Magnification: 40x). White bar represents data from limbal explants and proximal outgrowths, while black bar demonstrates data from distal growing 3D cell sheets. (*) means negligible count or zero positive cells expressing CK3. Data are expressed as mean \pm SEM.

ABCG2 - a putative marker of stemness, was positive in $6.0 \pm 1.7 \%$ of the outgrowths proximal to the explants and $9.8 \pm 2.0 \%$ distal to the explants (Fig. 2). The expression of pluripotency marker CK15 close to the limbal explants was $15.6 \pm 2.5 \%$, while in the cells far from the explants was $54.3 \pm 1.2 \%$. CK19 staining was observed in $12.0 \pm 1.3 \%$ of the cells near to the explants, and in $20.3 \pm 2.7 \%$ of the cells farther from the explants (Fig. 2). 

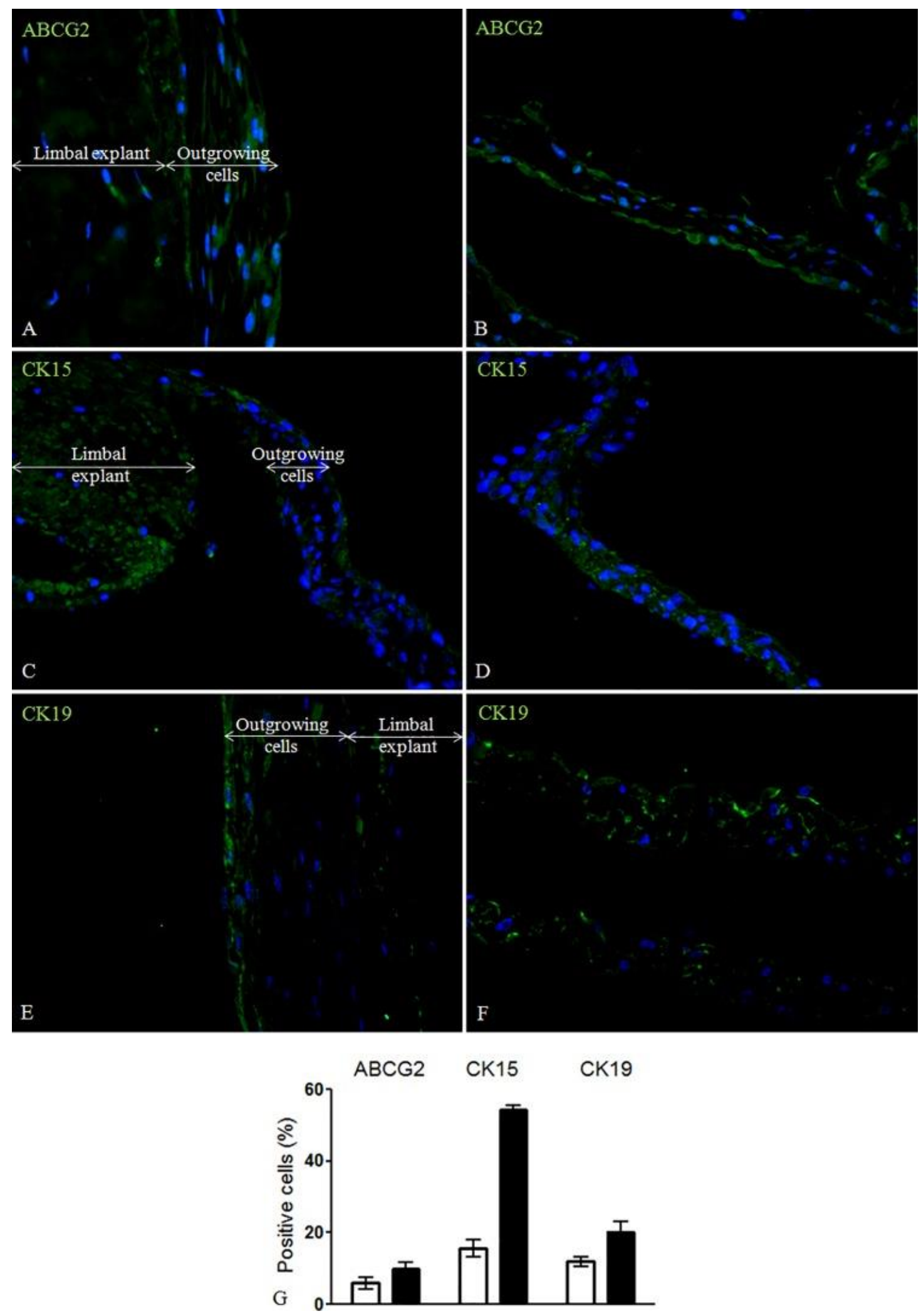

Figure 2.Limbal explants and 3D cell outgrowth stained for stemness markers.

Limbal explant and outgrowing cells proximal (A, C, E), and 3D cell outgrowth distal to the explants (B, D, F) are shown stained for ABCG2, CK15 and CK19, respectively (Magnification: 40x). White bars represent data from limbal explants and proximal 
outgrowths, while black bars demonstrate data from distal growing 3D cell sheets. Data are expressed as mean \pm SEM.

Co-staining of the nuclear localized p63 and cytoplasmatic Vim, also part of the putative stem cell markers, were found to be positive in $8.6 \pm 0.1 \%$ and $67.3 \pm 3.7 \%$ of the cells, respectively. The proliferation marker Ki-67 showed positivity in 5.0 $0.1 \%$ of the cells (Fig. 3).

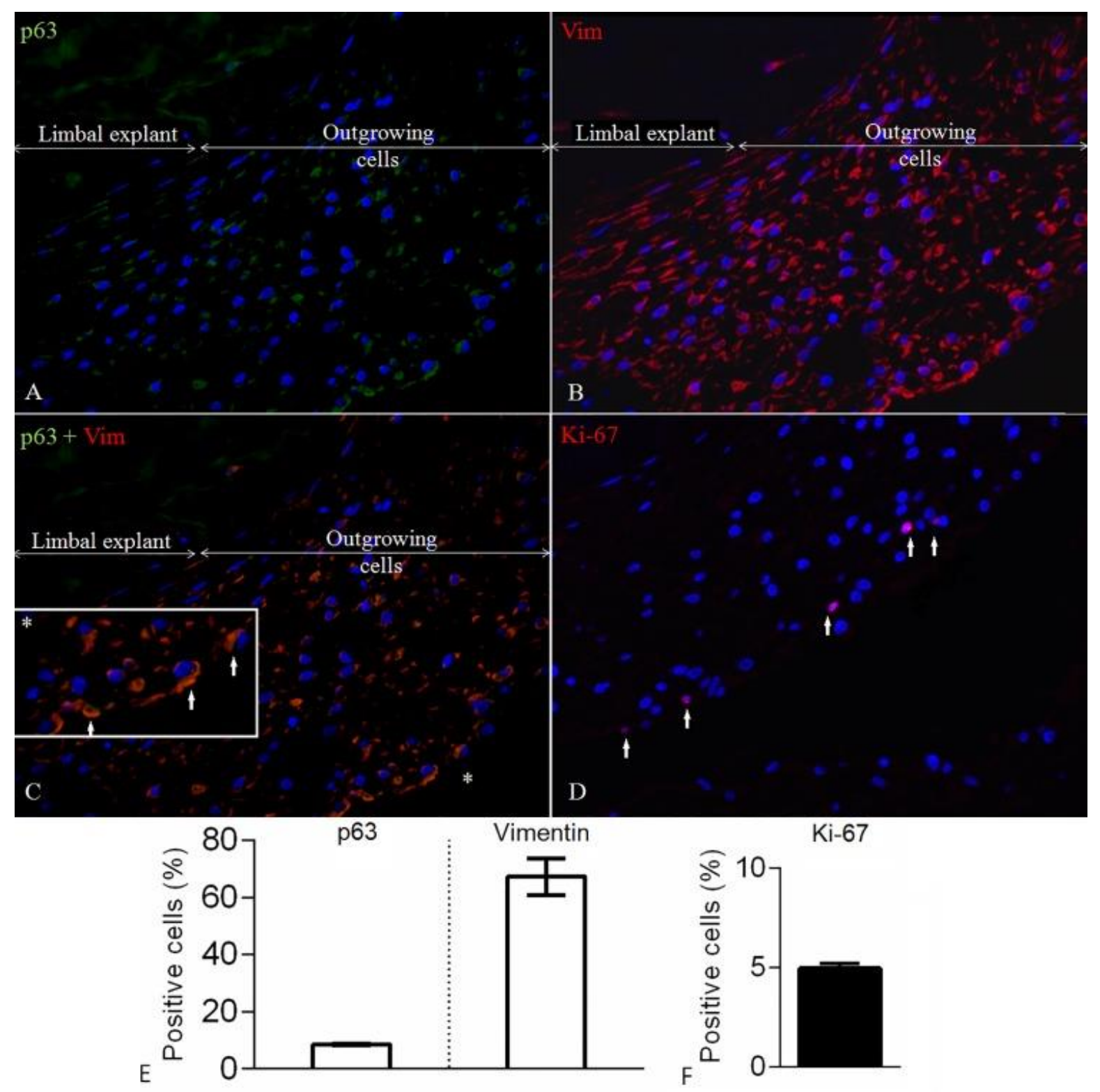

Figure 3. Limbal explants and 3D cell outgrowth stained for additional stemness and proliferation markers.

Limbal explant and proximal outgrowing cells stained for p63 $\alpha$ and/or Vim (A, B, C), and distal growing cells forming 3D structures being stained for proliferation marker Ki-67 (D) (Magnification: 40x). White bars represent limbal explants and proximal outgrowths, while black bar demonstrate data from distal growing 3D cell sheets. Data are expressed as mean \pm SEM. 
Staining was positive for collagen I, IV and V throughout the outgrowing cell sheets, creating a self-assembled, natural scaffold for the expanding 3D cell culture (Fig. 4).

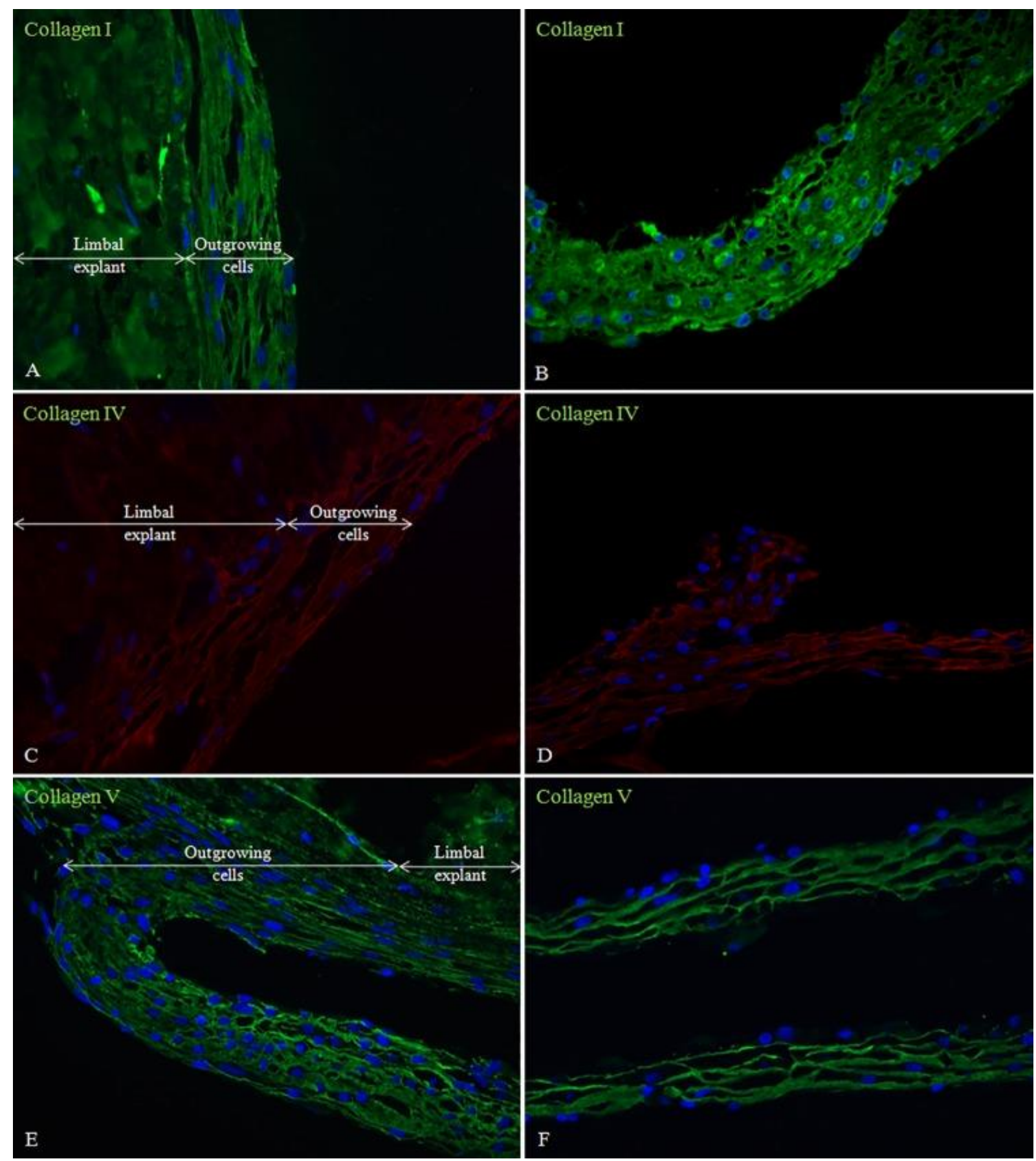

Figure 4. Limbal explants and 3D cell outgrowth stained for extracellular matrix proteins.

Limbal explant and proximal outgrowing cells (A, C, E), and 3D cell outgrowth distal to the explants (B, D, F) being stained for collagen I, IV and V, respectively (Magnification: 40x). 
The results of cell viability test showed a higher than $90 \%$ cell viability that was similar compared to the short term cultures (Fig. 5A,B).

The TEM analysis showed the stratified ultrastructure of the long-term ex vivo cultures and revealed desmosomes (cell-to-cell junctions) between adjacent cells (Fig. 5C).

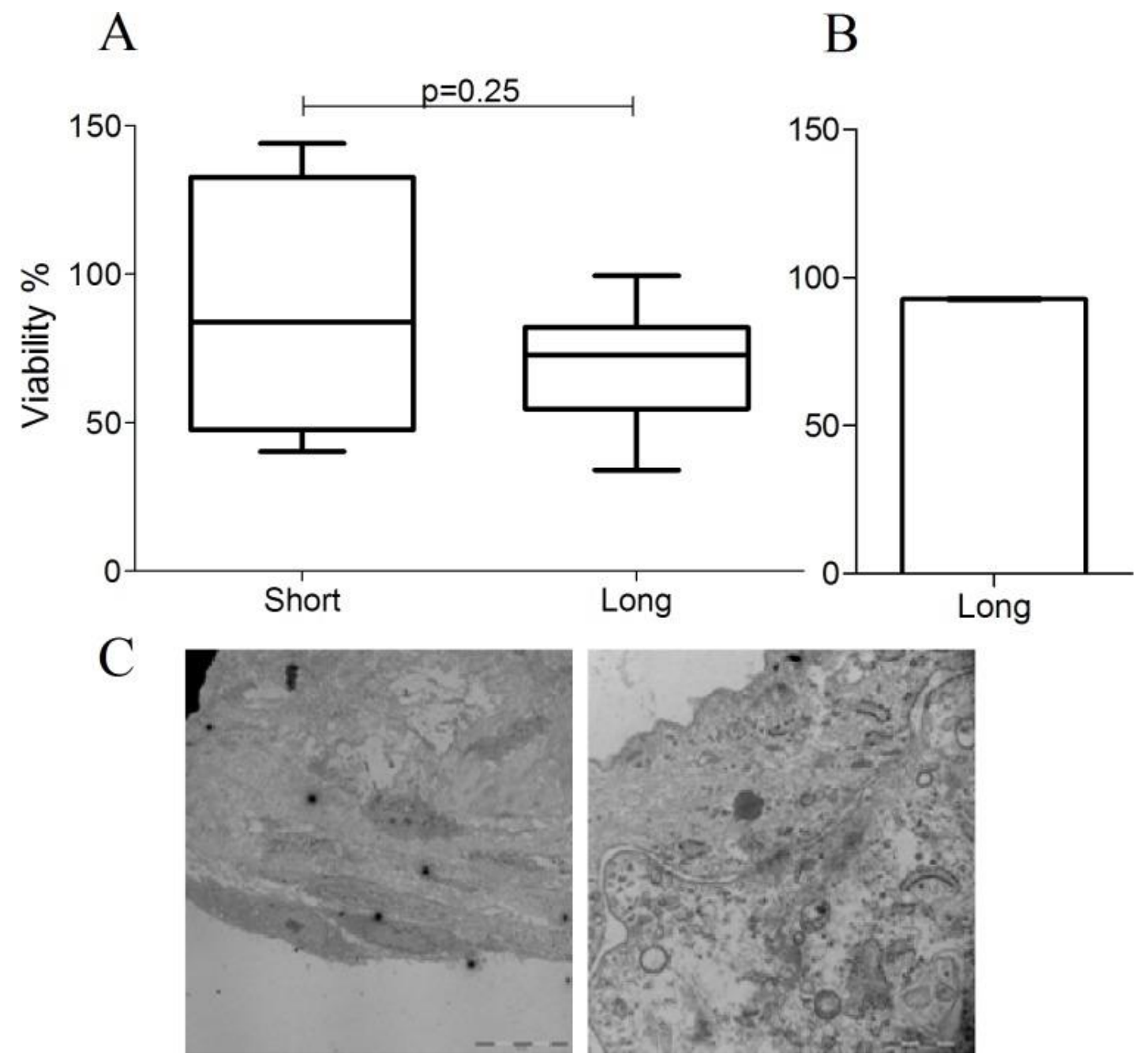

Figure 5. Cellular viability and ultrastructure of the long-term limbal cultures.

CellTiter-Glo ${ }^{\circledR}$ Luminescent assay (A) and Trypan blue exclusion test (B) revealed no significant difference between the cellular viability of the the long- and short-term LESC cultures, based on the ATP level measurements $(n=4)$. Long-term cultures showed an overall $>90 \%$ viability $(92.76 \pm 0.72 \%, \mathrm{n}=4)$, when tested by the Trypan blue exclusion test. The ultrastructure of the 3D sheets is shown in (C): left image shows the stratified arrangement of the cells (bar: $20 \mu \mathrm{m}$ ); right image shows the cell-to-cell-interactions and formation of a desmosome at the center (bar: $1 \mu \mathrm{m})$.

Immunophenotyping of the long-term cultivated LESCs was compared to the surface marker expression profile of short-term LESCs. 
Comparing the expression of CD117/c-kit $(0.6 \pm 0.1 \%)$, a marker of pluripotent hematopoietic progenitor cells in the long-term cultures versus short term cultures, the disappearance of this marker could be observed in the latter (Fig. 6). The CD34, another hematopoietic cell surface marker was not expressed on either the long-term $(0.8 \pm 0.3 \%)$ or the short-term LESCs. Chemokine receptor CXCR4 (22.4 $\pm 10.3 \%)$ which plays an important role in the regulation of stem cell migration was abolished in long-term compared to short term LESC cultures (Fig. 6). High expression of CD47 (95.0 $2.6 \%)$ indicates the viability and immunocompetence of both culture types. No expression of endothelial-related marker CD31/Platelet endothelial cell adhesion molecule (PECAM) could be detected on any of the cell types, excluding endothelial-related contamination (Fig. 6). Alterations in the cell surface adhesion molecules that are involved in the interaction with the surrounding ECM and other cells were further investigated, which revealed that CD146/MCAM (45.0 $03.0 \%)$ and CD166/ALCAM $(64.16 \pm 12.7 \%)$ are significantly decreased, while CD44/homing-associated cell adhesion molecule $(\mathrm{H}-\mathrm{CAM})$ is significantly increased $(73.4 \pm 3.1 \%)(\mathrm{p}<0.001)$ in the long-term LESC cultures compared to the short-term ones.

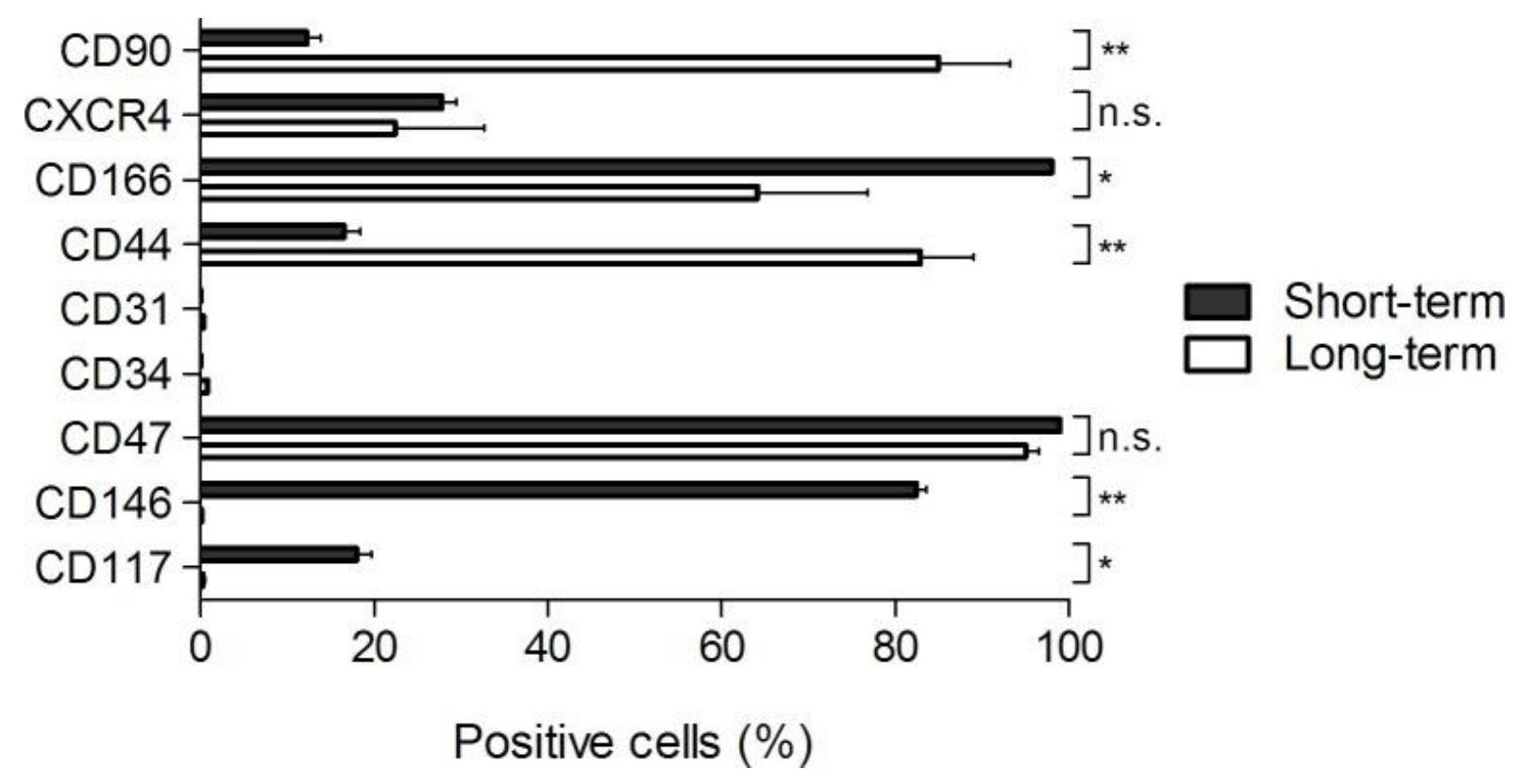

\section{Figure 6. Results of the FACS analyses in long- and short-term limbal cultures.}

A plot of the percent positive cells in the short- and long-term cultures \pm SD is shown. Colors represent different markers measured at different stages of cultivation, the change in expression is demonstrated by the connecting lines. 
6.2. Tissue engineering of the human corneal stroma - 3D model for Schnyder corneal dystrophy

Phase contrast images of ex vivo cultivated corneal stroma grafts showed cell outgrowth from the explant assuming fibrosblastic morphology within 2 weeks of cultivation, and continuous monolayer formation during the weeks 2-3. Upon reaching confluence, the cultures underwent stratification and formed a 3D structure after 4-5 weeks. (Fig.7)

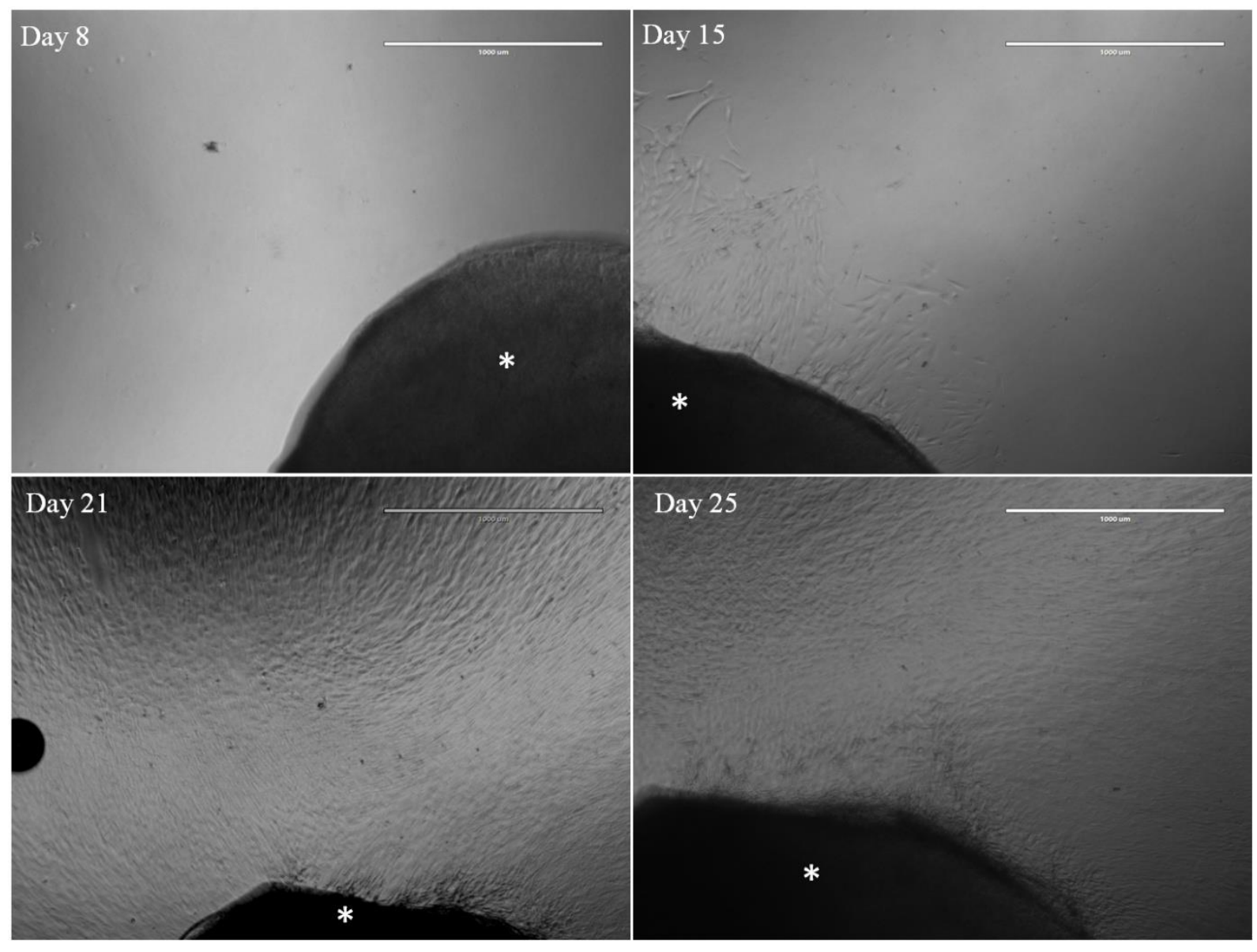

Figure 7. Corneal stromal cell outgrowth from explants (*) cultivated ex vivo. Representative images of long-term cultivated cells are shown; 3D layering of the cells becomes noticable within 3-4 weeks (Day 25 in the images shown). Scale bars represent 1000 $\mu \mathrm{m}$.

Immunofluorescent staining of long-term 3D stroma showed de novo ECM deposition abundant in multilamellar collagen type I, similar to a tissue of the native corneal stroma. (Fig.8) 

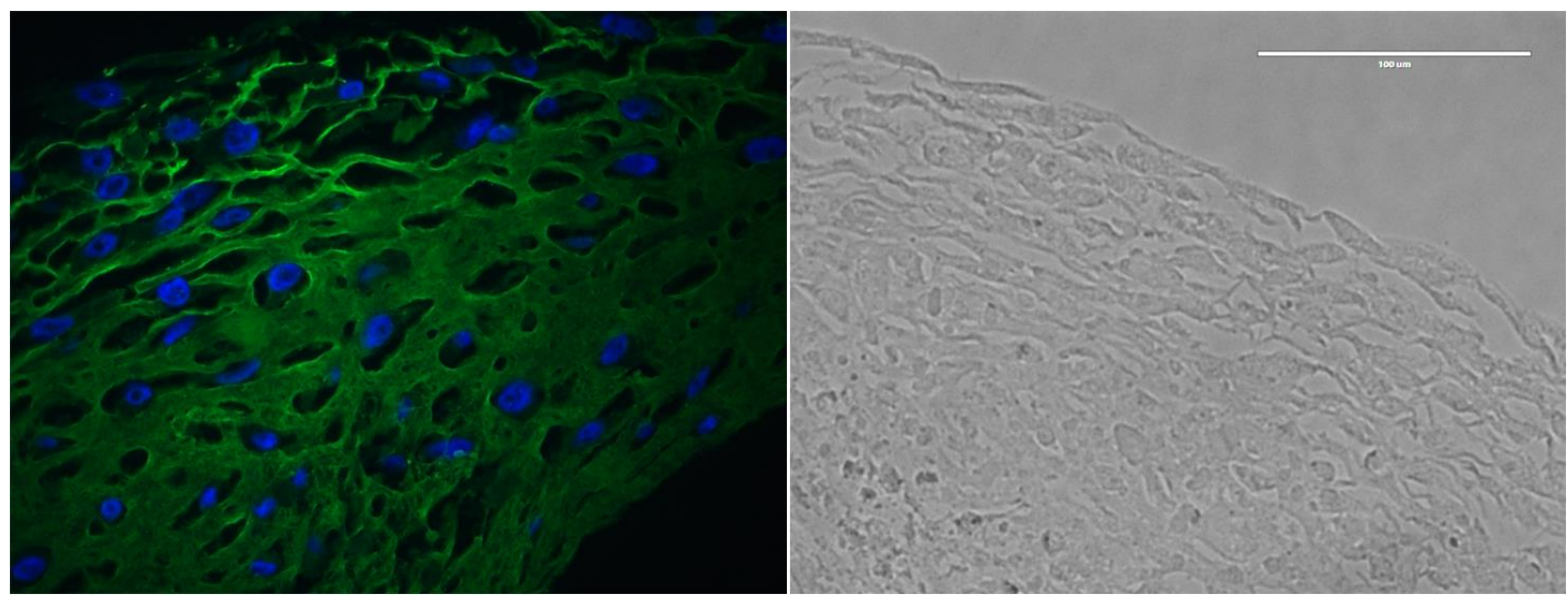

Figure 8. De novo ECM deposition of corneal stroma cells after long -term cultivation. Immunofluorescent staining for collagen I (left, magnification: 63x) and phase contract image (right, magnification: 40x) are shown accordingly.

TEM analysis of the long-term 3D stroma revealed heavy MLB formation, with AVs being seen in the untreated long-term cultivated corneal stroma. The effect of RAP treatment and serum deprivation/starvation enhanced the expression of MLBs and AVs, while the 3-MA treatment attenuated it. The mitochondria appeared to be intact under 3-MA treatment also. (Fig.9) 

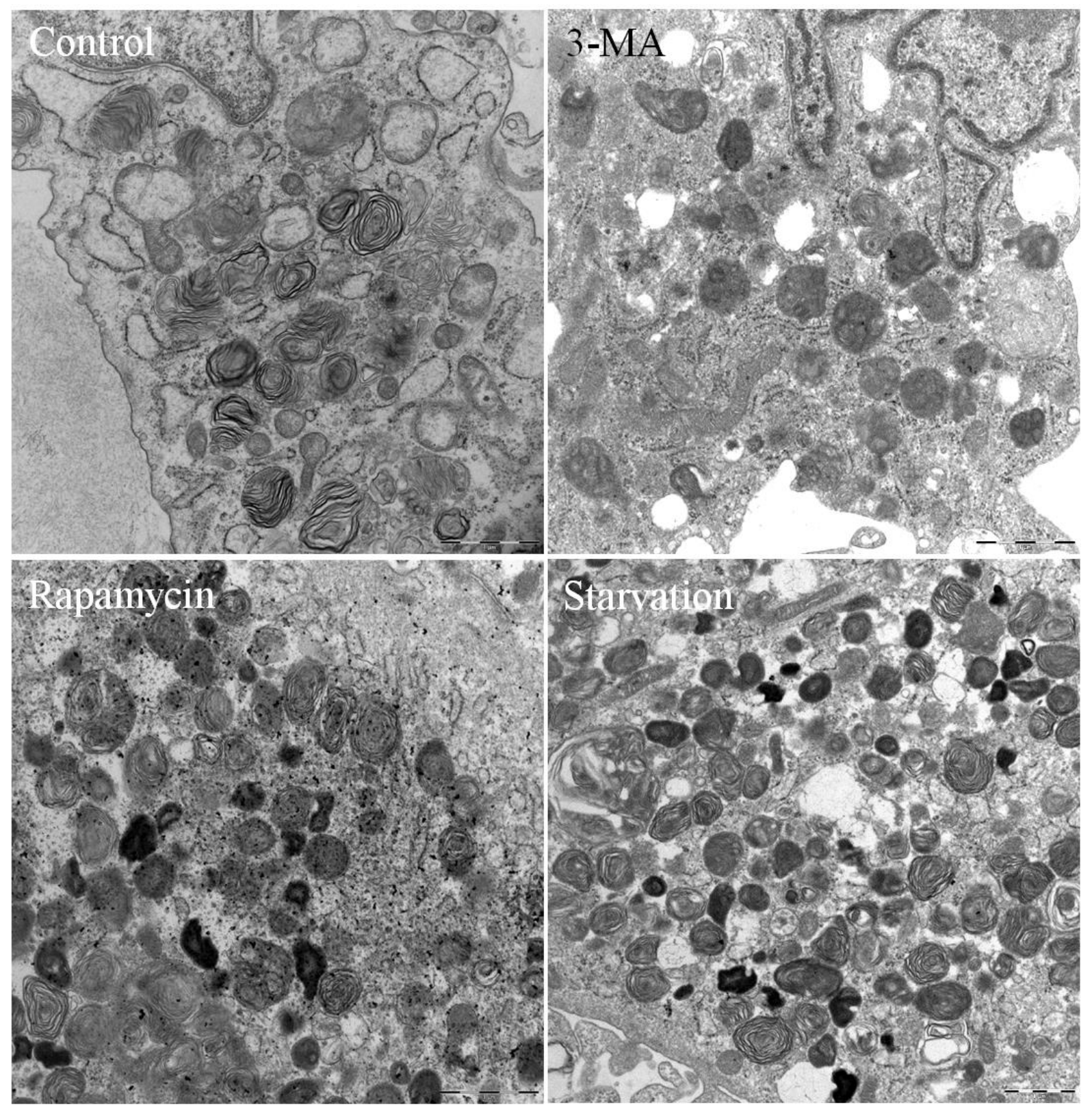

Figure 9. TEM of 3D long-term cultures of human corneal stroma and presence of MLBs and autophagic vacuoles. Scale bars represent $1 \mu \mathrm{m}$.

Similarly, immunohistochemical analysis of the long-term 3D stroma for the typical autophagy markers LC3 and p62, showed that before treatment, the 3D corneal stroma tissue contained positive AVs, while further induction of autophagy by RAP treatment and serum starvation enhanced the amount of AVs; treatment by 3-MA resulted in attenuated LC3 and p62 expression, and therefore presence of decreased number of AVs. (Fig.10) 


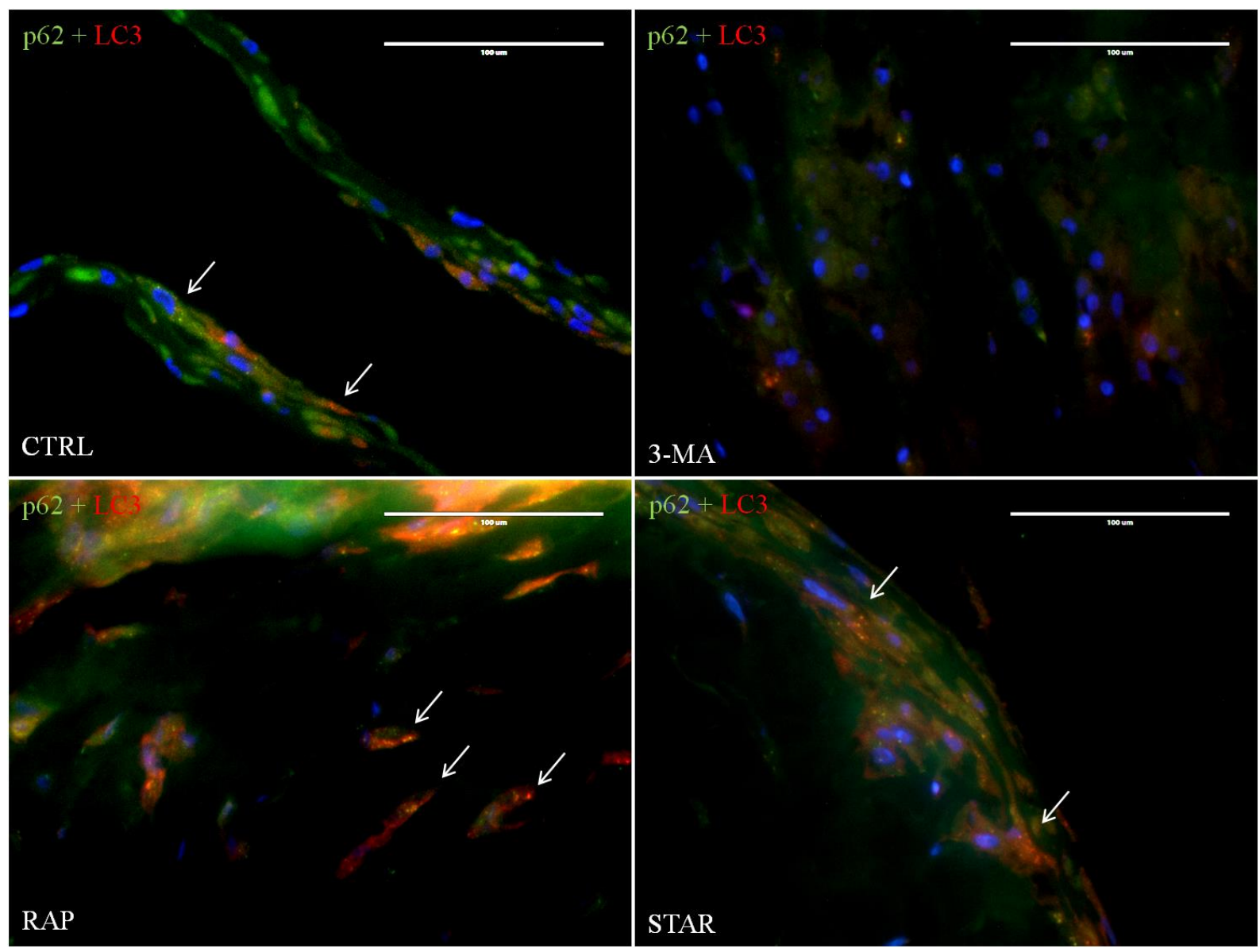

Figure 10. Immunohistochemical analysis of the 3D corneal stroma tissue for presence of autophagy. Scale bars represent $100 \mu \mathrm{m}$. 


\section{Discussion}

Tissue engineering has been a promising and a rapidly developing area of science in the last decades, while the use of stem cells in regenerative medicine to repair tissue damage and restore normal tissue function has been widely investigated. Stem cell-based disease modeling could be used to study disease mechanisms and potential therapies.Adult stem cells from the cornea have great potential for applications in regenerative medicine and stem cellbased disease modeling.

The stem cells of the corneal epithelium are located at the corneoscleral junction within the limbal niches. Diseases or trauma that can impair the LESCs or the special limbal microenvironment may lead to LESCD, which causes loss of the regenerative capacity of the ocular surface, a potential sight-threatening condition. The only treatment option for these patients is the replacement of the missing stem cell population. One of the possibilities is the ex vivo expansion and transplantation of LESCs with the help of carriers that is becoming widely accepted.

In our study, a successful cultivation of long-term LESCs without use of any scaffolds was performed, and characterization of such cultures morphologically and immunophenotypically was achieved. After more than three months of cultivation without passaging, the cells developed a transparent, intact 3D sheet structure that could be harvested without the need of proteolytic enzymes, only using a forceps for lifting or air-lifting. The microscopic morphology of these ex vivo structures revealed a well-organized, stratified tissue, similar to that found in vivo. DAPI nuclear staining showed thatcells were embedded in the outgrowing multilayered ECM outside the explant tissue, but could not be found in the donor tissues any longer, after long-term cultivation. The disappearance of the cells in the donor tissue explants suggest that, during the long-term cultivation process, the cells migrated out from the explants and moved towards the cell culture surface of the culture plate, while depositing their own ECM. We named this process the 'empty snail-shell phenomenon'. Immunohistochemical analysis confirmed that the ECM is composed of collagen I, IV and V. Studies have shown that conventional and compressed collagen gel sheets could serve as biomaterial scaffolds that support the creation of a confluent and multilayered sheet, consisting of stem- and differentiated cells, that could be transplanted [27]. Limbal explant cultured on Vitrigel converted from collagen I exhibited a partially stratified epithelium and p63 expression, while at the same time, matrix associations or presence of Vitrigel support 
was formed facilitating stemness in the culture dish [28]. Laminin-coated compressed collagen gel containing keratocytes used as a scaffold for limbal stem cell cultures supported the stratification, differentiation of a transparent tissue [29]. As collagen $I$ is the most abundant portein in the corneal stroma in vivo, it could be a suitable scaffold for corneal tissue engineering. Our results indicate that LESCs are able to produce their own ECM containing collagen $\mathrm{I}$, that could replace the need for using a scaffold or a feeder-layer to attain a stratified, 3D structure. By removing any foreign components that could have even a minimal antigenicity, we could eliminate the risk of immunogenic reactions. Most transplantation studies use short-term cultures of LESCs on different biologic or synthetic scaffold, without considering that long-term cultures can make self-assembled, own-made scaffold, which can be ideal for transplantations. Furthermore, our cultures could synthesize collagen IV, commonly known as a major component of the basement membrane, and collagen $\mathrm{V}$, as well as demonstrate stratification without any direct induction. The arrangement and composition of the deposited, insoluble ECM in the long-term cultures suggests ECM components could serve as a support for the stratification and multilayerformation. TEM examination showed desmosomes in the ultrastructure of the cultures that indicated an adequate cell-to-cell adhesion, that can provide a high mechanical strength.

Several markers were suggested for the identification of LESCs, but to date, a specific marker has not been found, therefore, a combination of putative stem cell markers and lack of differentiation related markers is in use.

One of the corneal epithelial differentiation markers, CK3 is an intermediate filament expressed by all the cell layers of the mature corneal epithelium, but not by conjunctival epithelial cells [30]. It is also absent in limbal crypts in vivo [3], although expression of CK3 has been reported in cadaveric limbal tissues, but only in the superficial layer, while it did not affect the basal layers $[8,31]$. Human limbal explant cultures showed a declining positivity of CK3 during a 3 week culturing period [32]. A study comparing superficial and full-thickness limbal tissue-derived cells reported that the positivity was more prominent in the superficial cultures after 3 weeks [33]. Our results showed no positivity for CK3 in the long-term cultures, which could imply a gradual depletion of differentiated cells or the cells return to a previous dedifferentiated state and 'drop' this marker.

CK12, the other epithelial differentiation marker, similarly to CK3 is not expressed in the basal layer of the corneal epithelium [34], although qPCR analysis could show weak 
expression in the limbal epithelium compared to an abundant expression in the other parts of the corneal epithelium [35].

Our samples showed CK12 positivity in one-fifth of the cells proximal to the tissue explants, that decreased at the distal part of the explants. The absence or presence of a relatively low expression of corneal differention markers in our cells implies that the cells are in a relatively undifferentiated state after long-term cultivation.

ABCG2, a cell surface transporter protein, has been proposed as a universal stem cell marker. The ABCG2 expression marks the side population (SP) phenotype based upon the ability to efflux Hoechst 33342 dye [36]. It plays an important role in the maintenance of undifferentiated state of stemness, as overexpression and underexpression of this marker can affect the lineage commitment of the cells [37]. A high expression of ABCG2 is restricted to the basal and suprabasal layers of the limbus in vivo [4, 8, 35, 37-39]. In our study, a $6.0 \pm 1.7 \%$ expression of this stemness marker was observed proximal to the explants, and $9.8 \pm 2.0 \%$ expression was detected in the $3 \mathrm{D}$ cell outgrowth distal to the explants, that is similar to that observed in human superficial limbal explants cultures [33].

Expression of putative stem cell marker CK15 has been reported in limbal basal epithelium in fetal and adult limbus in vivo as well as in cultured limbal epithelial tissue [40, 41]. This was in accordance with our results, which revealed CK15 positivity in the proximal and distal part of the cell outgrowths.

CK19 is an intermediate filament protein and a suggested marker for the epidermal progenitors in skin follicles [42], which has controversially been considered by some sources as a marker of conjunctival epithelium [43-45]. It can be found in the basal and peripheral regions of the limbus in vivo [3, 31], and its expression shows a decreasing tendency in explant cultures in vitro $[32,33]$. In our samples, CK19 was positive in $12.0 \pm 1.3 \%$ of the outgrowing cells proximal to the limbal explants, and in higher percentage $(20.3 \pm 2.7 \%)$ in the $3 \mathrm{D}$ cell sheets distal to the explants.

Positive expression of ABCG2, CK15 and CK19 indicates that even after long-term cultivation, a small amount of cells maintain stem cell characteristics in a three-dimension environment, which can be a good indicator of their potential for use in clinical transplantation. 
The presence of p63 $\alpha$, a nuclear progenitor marker, is a putative LESC marker, with a positivity which is not selective for stem cells only, but it labels also young transient amplifying cells in the cornea [46]. It has been also shown that the the expression of p63 $\alpha$ indicates a success of limbal transplantation, since cultures with more than $3 \%$ p $63 \alpha$ positive cells have better prognosis post-transplantation [47]. Our samples revealed high expression of p63 around the explants $(8.6 \pm 0.1 \%)$, which is a promising result for the outcome in future clinical use.

The presence of Vim, a cytosceletal intermediate filament, has been shown in cells located in the limbal crypts, but it has not been detected in the limbal epithelium in situ [3, 39]. Cultured limbal basal epithelial and stromal cells show high levels of Vim [33], and in contrast, commited limbal and epithelial cells show no sign of Vim positivity. This indicates that Vim can be a marker of limbal progenitor cells [33]. Our samples showed high expression of Vim around the limbal explants that can probably be explained by the presence of tissue explants or other matrix associations existing in the cultures, and further proves the presence of undifferentiated progenitor cells. P63 and Vim co-localization could also be detected, which resembles the native limbus per se.

Overall, the expression pattern of ABCG2, CK19, Vim and p63 $\alpha$ was similar to the findings by others regarding the limbal crypt $[3,39]$.

The expression of Ki-67 in the nucleus is associated with cell proliferation and growth. In tumor cells, its expression is used as a prognostic marker.for survival rate. In our samples, $\mathrm{Ki}-67$ showed a low expression distal to the explants, which proves that after the long-term cultivation, the cells were capable of maintaining a low proliferative capacity.

A study that followed the short term (3 weeks) cultivation of limbal explants found a decrease of CK3 expression and an increase in CK19 and Vim positivity in the cell cultures. The decreased expression of Ki-67 was then linked to reaching confluency in the cell culture dish [32].

In a previous study of various rabbit limbal autograft transplantation models, a six-month follow-up of autologous heterotopic transplantation of limbal explants into the central part of the cornea showed the disappearance of p63 and Ki-67 markers, and the appearance of CK3 positivity [48]. The study pointed out that the limbal microvascular net and the limbal stroma 
play an integral role in maintaining the stemness and proliferation of LESCs and avoiding their differentiation.

Others have investigated the differences in the expression of progenitor, differentiation, and proliferation markers in the cell cultures obtained from four limbal regions (superior, nasal, inferior and temporal) and found similar staining tendencies in the examined areas: the CK3 expression was absent in all cultures, CK19, Vim and p63 showed high expression in both, the basal and suprabasal layers, while a moderate ABCG2 positivity could be observed in all the layers cultured epithelia. Although the explants of superior origin demonstrated the greatest epithelial thickness and number of cell layers, Ki-67 expression was not significantly higher in such cultures [49].

CD47, a hematopoietic cell surface marker, serves as a 'don't eat me' signal, as it prevents marcophages from engulfing the healthy/viable-marker bearing cells [50-52]. The viability did not change significantly in long-term cultures in comparison to short-term cultures, as the expression of CD47 after more than 3 months cultivation was still high. This was also supported by two different viability assays (CellTiter-Glo ${ }^{\circledR}$ Luminescent assay and Trypan blue exclusion test).

We found that the expression of CD117/c-kit an early progenitor/pluripotent stem cell marker, and CXCR4, a chemokine receptor for proliferating cells, diminished in long-term cultures, even though every fifth-sixth and every fourth cell showed positivity in the shortterm cultures for both markers, respectively. A possible explanation for the decline in the expression of these markers could be that after confluence and stratification was achieved, the space for further expansion became restricted. Furthermore, short- and long-term cultures showed a lack of hematopoietic marker CD34 and endothelial marker CD31 expression.

The expression of the mesenchymal/ epithelial marker CD90/Thy-1 increased over time and up to 7-fold in the long-standing cultures versus the short-term LESC cultures. Although CD90/Thy-1 has been located on cornea epithelial cells as well [53], its expression on longterm cultures of LESCs might refer to a commitment or a trans-differentiation potential towards epithelial lineage when cultured over longer periods of time. A previous study has shown that decreasing CD90 expression promotes differentiation of MSCs and also leads to a decrease in CD44 and CD166 expression [54]. 
During characterization of the cultured LESCs, some yet not described markers were found to be expressed, such as CD44/HCAM, CD144/VE-Cadherin, CD146/MCAM and CD166/ALCAM. These markers could also be localized in the limbal epithelium in situ.

The in situ expression of cell adhesion molecules in the limbus has been previousy described by our group [26]. CD44/HCAM was found in cells of the apical layer, while CD146/MCAM and CD166/ALCAM were expressed at the basal layer of the limbus. In our long-term cultures, a 4-4.5-fold increase in the expression of CD44 was observed compared to the shortterm cultures. The CD146/MCAM expression showed a donor-dependent variability, but the levels of expression did not differ within the cultures themselves. CD166/ALCAM expression was decreased 2.5-fold in the long-term cultures. Changes in the adhesion molecule expression could be associated with the development of ECM deposition [50, 51].

In summary, we successfully isolated, expanded and long-term cultivated LESCs. The outgrowing cells were able to migrate from the explants, create a stratified structure and deposit a 3D ECM, generating a transparent tissue that could be easily manipulated. The cells expressed stemness-related markers, but also a commitment toward epithelial differentiation. After long-term cultivaton, the migration and proliferation potential diminished. The cultures expressed a sufficient amount of biomarkers or fingerprint that can indicate a possible clinical success in case of future transplantation.

In the second part of our study, ex vivo long-term cultures of CSMSCs was established, that could possibly model Schnyder corneal dystrophy, and a mechanism for its potential resolution is being proposed.

Cell cultures derived from central corneal stroma explants have been known to show different characteristics than cells residing in the in vivo corneal stroma [55]. They are capable of a three-lineage differentiation, and express markers of MSCs, thus fulfilling the criteria for defining MSCs $[18,20]$. These cells also lack markers of hematopoietic lineage or activated cells, and further studies suggest that they can play an important role in corneal regeneration after tissue injury, as a result of their immunosuppressive properties [20]. The cultured corneal stroma cells show no expression of CD34, a keratinocyte marker, and this phenotype appeared to be stable even after 10 passages $[20,56]$.

In our study, we isolated and cultivated cells from the central part of the human corneal stroma according to a protocol previously described by our group [20]. The microscopic 
morphology of these long-term cultures showed a well-structured, multilayered 3D tissue resembling the cornea stroma structure in situ. Immunofuorescent staining revealed that a de novo synthesized ECM in the 3D structure is composed mainly of collagen I. This collagen is the main structural protein in the corneal stroma, and its highly organized fibrils that are narrower than in other tissues, located into stromal lamellae, play an important role in the ultrastructure of the stroma. The properly arranged ultrastructural complex provides the optic transparency of the cornea, and its disturbance causes reduced transparency and therefore impaired vision. In the ECM, collagen I creates a network with other matrix elements such as type V collagen, fibril-associated collagens with interrupted triple helices (FACITs) and small leucine-rich proteoglycans (SLRPs) [57]. Disarrangement of collagen I fibrils in the stroma can lead to corneal transparency complications such as corneal scarring [58-61]. In one study, the human corneal stromal stem cells (hCSSCs) isolated from the cornea limbal stroma and cultured in selective stem cell media, and keratocyte-derived corneal fibroblasts cultivated in serum containing media, were compared; it was found that hCSSCs produced an ECM that had greater resemblance to the stroma in vivo than the keratocyte-derived corneal fibroblast culture, and it also contained collagen I, V and VI [62].

Beside these, other cellular components such as crystallins are also important for maintaining corneal transparency, as they confer transparency to the stromal resident cells - the keratocytes.

It has been known that cultivation of keratocytes in serum-containing media generates differentiation into fibroblasts and partly myofibroblasts [64]. Corneal fibroblasts can create a self-assembled 3D structured tissue consisting of collagen type I (in serum and ascorbic acid supplemented media) that shows close histological resemblance to human native corneal stroma [65]. These 3D human fibroblast cultures grown over long-term on a disorganized collagen substrate have been found to have proteoglycan deposition and sulfation throughout the produced multilayered structure [66]. TEM images of such cultures after 8 weeks reported no intracellular changes or presence of MLBs or any other storage or clearance pathways' activation.

Examination of the ultrastructure of our 3D cultures revealed that after long-term cultivation, spontaneous intracellular structural changes develop, as abundant numbers of MLBs appeared. MLBs are cytoplasmic organelles of lysosomal nature, that could be present under normal and also under pathologic conditions. and their appearance is linked to intracellular 
lipid metabolism. In lung type II alveolar cells, MLBs play an important role in the surfactant storage and secretion process. It has been shown that the biogenesis of MLBs in these cells is an autophagy-dependent mechanism, and inhibition of autophagy with 3-MA can block the MLB expression in the lung in type II alveolar Mv1Lu cells transfected with Mgat5 [24]. Stimulation of autophagy by serum starvation can result in an increased size of MLBs in Neimann-Pick type C-mimicking drugU18666A-induced cholesterol-rich lysosomal vacuoles [63].

Autophagy as a basal cellular degradation mechanism is present in many parts of the eye, in fact, all cell types need this process to remove proteins and cell organelles that are not functional,and to maintain the physiological state and balance of the cells in the eye [64]. Autophagy is accountable for the maturation of lens fiber cells, removal of shed outer segments from photoreceptors in the retinal pigment epithelium (RPE); on the other hand, it also plays a role in corneal pathology, such as dystrophies affecting the corneal endothelium and stroma [65]. Defects in the autophagy clearance system have been known to cause pathogenic changes in certain diseases; in type 2 granular corneal dystrophy (GCD2), accumulation of mutant TGF $\beta$-induced protein (TGF $\beta$ Ip) causes hampered autophagic clearance and ultimately vision impairment [66]. It has been reported that corneal fibroblasts from homozygous GCD2 patients exhibit a significantly higher LC3-II and p62 expressions compared to wild type (WT) fibroblasts [67]. When wounded, quiescent corneal stromal keratocytes become activated and undergo transdifferentiation into myo/fibroblasts through activation of the TGF $\beta$ signalling. Scar tissue formation can lead to disturbed ECM formation, and eventually hazy cornea [68].

In our samples, the presence of autophagy was proved by immunofluorescent staining with markers for autophagy (LC3 and p62) after autophagy induction with RAP and serum starvation treatment, as well as inhibition with 3-MA treatment, which showed an inversely related increase and decrease in the expression of these markers, respectively. TEM results showed that autophagy inhibition reduces the number of MLBs and leads to formation of dense vacuoles that are processed or degraded through the MLB pathway. When cells were treated with RAP or exposed to serum stravation, the number and size of MLBs increased.

The intracellular changes becoming apparent in the morphology of CSMSC after long-term cutivation is similar to that seen in SCD, as large amounts of MLBs accumulate in the cells' cytoplasm. Likely, the long-term cultures undergo spontaneous intracellular changes 
resemblant of MLBs and that of SCD - a rare autosomal dominant dystrophy characterized by progressive, abnormal cholesterol and phospholipid depositions in the cornea [69]. Genetic studies show that SCD is caused by one of numerous mutations in the UBIAD1 gene located on chromosome 1p36. This gene encodes a protein linked to lipid metabolism [70,71]. The lipid deposits in SCD consist mainly of multilamellar vesicles with unesterified cholesterol and phospholipids, with a lesser contribution of cholesteryl ester lipid droplets [72]. The structure of MLBs suggests a local lipid metabolic disturbance in the pathogenesis of SCD. To date, no treatment modality is available for stopping or slowing down SCD progression, nor there is a way to rid the cells off the MLBs.

In summary, the long-term cultivated CSMSCs over 3 months and without any passaging, are hereby considered as nearly as close model for studying corneal dystrophy as the in vivo condition. The process of producing and self-assembling the corneal stroma ex vivo, with strong expression of collagen type $\mathrm{I}$, and the evidence for presence and inhibition of autophagy in these 3D structure, thus decreasing the formation of MLBs (shown in Fig.11), can serve the role of slowing down the progressive loss of stromal transparency in SCD or any other condition involving MLBs and/or autophagy degradation pathway involvement. This can certainly have basic and transplantational implications, serving as a model for ex vivo studies on SCD, as well as therapeutic developments for treatment of this rare, but sightthreatening corneal dystrophy.

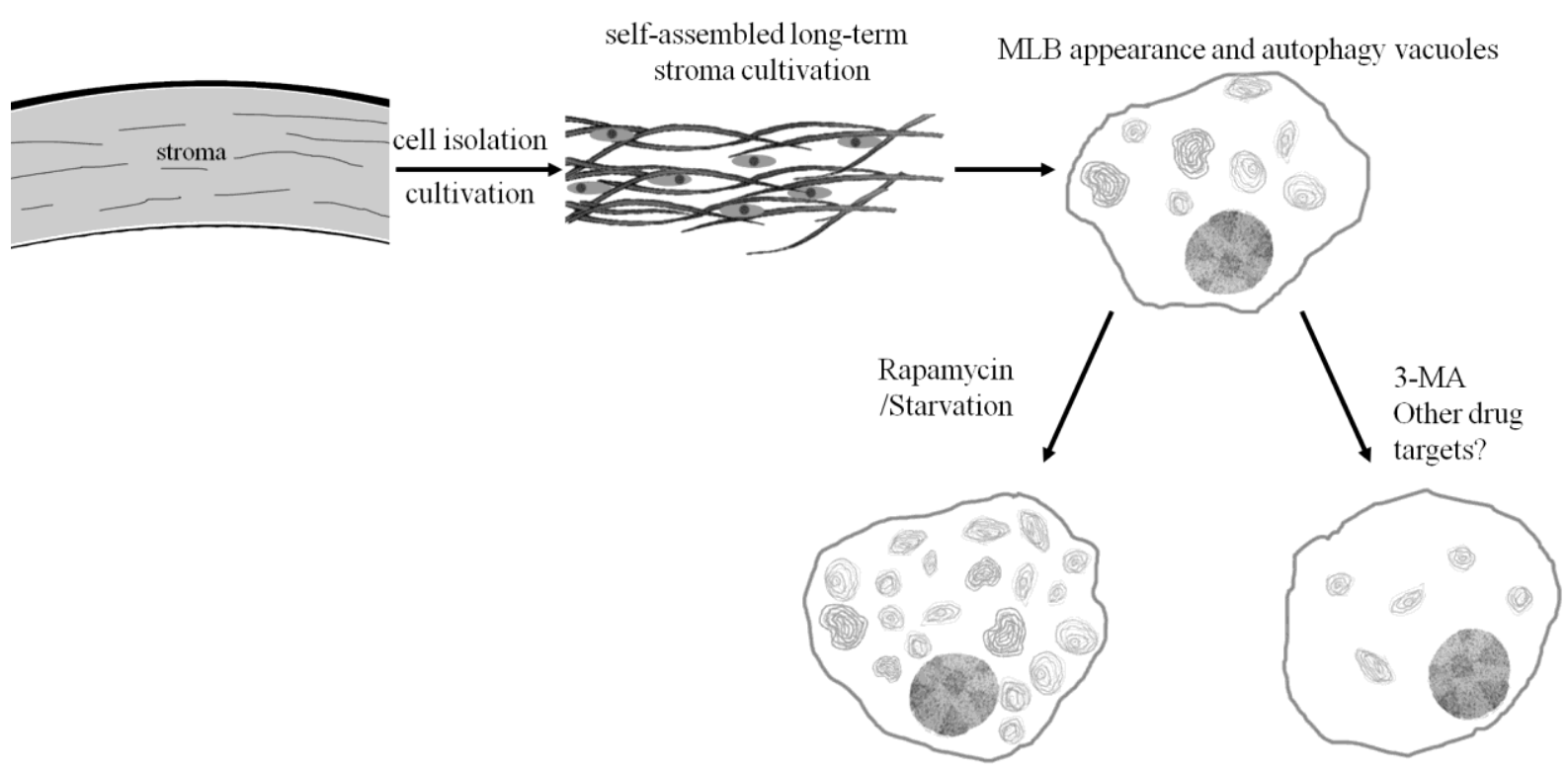

Figure 11. Proposed mechanism of Schnyder corneal dystrophy formation and cleareance of MLBs - potential implication for drug development. 


\section{Summary}

Adult stem cells from the cornea have great potential for regenerative medicine applications and stem cells-based disease modeling.

Transplantation of ex vivo cultivated cornea limbal epithelial stem cell (LESC) is used successfully for treatment of limbal stem cell deficiency (LESCD).In our study, long-term cultures of LESCs were developed and characterized for future tissue engineering and clinical applications. The limbal tissue explants were cultivated and expanded for more than 3 months in medium containing serum as the only growth supplement and without use of scaffolds. Viable 3D cell outgrowth from the explants was observed within 4 weeks of cultivation. The outgrowing cells were examined by immunofluorescent staining for putative markers of stemness (ABCG2, CK15, CK19 and Vimentin), proliferation (p63 $\alpha, \mathrm{Ki}-67)$, limbal basal epithelial cells (CK8/18) and differentiated cornea epithelial cells (CK3 and CK12). Morphological and immunostaining analyses revealed that long-term culturing can form stratified 3D tissue layers with a clear extracellular matrix deposition and organization (collagen I, IV and V). The LESCs showed robust expression of $\mathrm{p} 63 \alpha, \mathrm{ABCG} 2$, and their surface marker fingerprint (CD117/c-kit, CXCR4, CD146/MCAM, CD166/ALCAM) changed over time compared to short-term LESC cultures. Overall, we provide a model for generating stem cell-rich, long-standing 3D cultures from LESCs which can be used for further research purposes and clinical transplantation.

Schnyder corneal dystrophy (SCD) is a rare, progressive corneal stromal disease causing bilateral opacification associated with presence of multilamellar bodies (MLBs) within the stroma cells. The MLBs are concentric cytoplasmic membranes which form through an autophagy-dependent mechanism. In our study we developed an ex vivo 3D modell of the corneal stroma and SCD by long term cultivation of corneal stroma-derived mesenchymal stem-like cells (CSMSCs) that are multipotent stem cells located in the central corneal stroma.CSMSCs were isolated from the central cornea and cultivated long-term for more than 3 months to achieve spontaneous 3D outgrowth. The 3D tissues were then examined by transmission electron microscopy (TEM) for presence of MLBs, and by immunofluorescent labelling against markers for autophagy (p62, LC3). Autophagy was induced by classical serum starvation or rapamycin (RAP) treatment $(50 \mathrm{nM})$, and inhibited by the autophagy inhibitor 3-methyladenine (3-MA, 10mM) for 24 
hours. CSMSCs can form spontaneously 3D outgrowths over a 3-4 weeks period, depositing their own extracellular matrix containing collagen I. TEM confirmed the presence of MLBs in the long-term (>3 months) 3D cultures, which became more abundant under starvation and RAP treatment, and decreased in number under autophagy inhibition with 3-MA. The presence of autophagy and its disappearance could be confirmed by an inversely related increase and decrease in the expression of LC3 and p62, respectively.MLB formation in long-standing CSMSC cultures could serve as a potential ex vivo model for studying corneal stroma diseases, including SCD. Inhibition of autophagy can decrease the formation of MLBs, which may lead to a novel treatment of the disease in the future.

\section{Acknowledgements}

First of all, I would like to thank my supervisor, Prof.Dr. Goran Petrovski, for his patient guidance, support and for providing me numerous opportunities during my studies. Without his encouragement and help this dissertation would not have been possible.I have been very fortunate to have him as my supervisor.

I would like to express my gratitude to Prof. Dr. Andrea Facskó, for giving me the opportunity to carry out my doctoral research in the Department of Ophthalmology at University of Szeged.

I am forever thankful for the support and friendship provided by the other members of the Stem Cells and Eye Research Laboratory: Dr. Zoltán Veréb, Dr. Natasha Josifovska, Dr. Richárd Nagymihály, Dr. Luna Djirackor, Dr. Réka Albert, Dóra Eszes and Dr. Mária Szatmári-Tóth.

Last but not the least, I would like to thank my family for their endless support and encouragement throughout my years as a $\mathrm{PhD}$ student and during writing this thesis, without which I would not come this far. 


\section{References}

1. $\quad$ Graw, J., Eye development. Curr Top Dev Biol, 2010. 90: p. 343-86.

2. Meek, K.M. and C. Knupp, Corneal structure and transparency. Prog. Retin. Eye Res., 2015. 49: p. 1-16.

3. Shanmuganathan, V.A., et al., Morphological characteristics of the limbal epithelial crypt. Br J Ophthalmol, 2007. 91(4): p. 514-9.

4. $\quad$ Singh, R., et al., Impression cytology of the ocular surface. Br J Ophthalmol, 2005. 89(12): p. 1655-9.

5. Dziasko, M.A. and J.T. Daniels, Anatomical Features and Cell-Cell Interactions in the Human Limbal Epithelial Stem Cell Niche. Ocul Surf, 2016. 14(3): p. 322-30.

6. Pellegrini, G., et al., Location and clonal analysis of stem cells and their differentiated progeny in the human ocular surface. J Cell Biol, 1999. 145(4): p. 769-82.

7. Joe, A.W. and S.N. Yeung, Concise review: identifying limbal stem cells: classical concepts and new challenges. Stem Cells Transl Med, 2014. 3(3): p. 318-22.

8. Chang, C.Y., et al., Acute wound healing in the human central corneal epithelium appears to be independent of limbal stem cell influence. Invest Ophthalmol Vis Sci, 2008. 49(12): p. 5279-86.

9. Kenyon, K.R. and S.C. Tseng, Limbal autograft transplantation for ocular surface disorders. Ophthalmology, 1989. 96(5): p. 709-22; discussion 722-3.

10. Pellegrini, G., et al., Long-term restoration of damaged corneal surfaces with autologous cultivated corneal epithelium. Lancet, 1997. 349(9057): p. 990-3.

11. Haagdorens, M., et al., Limbal Stem Cell Deficiency: Current Treatment Options and Emerging Therapies. Stem Cells Int, 2016. 2016: p. 9798374.

12. Nguyen, K.N., et al., Native and synthetic scaffolds for limbal epithelial stem cell transplantation. Acta Biomater, 2017.

13. Reinhard, T., et al., Long-term results of allogeneic penetrating limbo-keratoplasty in total limbal stem cell deficiency. Ophthalmology, 2004. 111(4): p. 775-82.

14. Henderson, T.R., D.J. Coster, and K.A. Williams, The long term outcome of limbal allografts: the search for surviving cells. Br J Ophthalmol, 2001. 85(5): p. 604-9.

15. Sangwan, V.S., et al., Early results of penetrating keratoplasty after cultivated limbal epithelium transplantation. Arch Ophthalmol, 2005. 123(3): p. 334-40.

16. Vascotto, S.G. and M. Griffith, Localization of candidate stem and progenitor cell markers within the human cornea, limbus, and bulbar conjunctiva in vivo and in cell culture. Anat Rec A Discov Mol Cell Evol Biol, 2006. 288(8): p. 921-31.

17. Michelacci, Y.M., Collagens and proteoglycans of the corneal extracellular matrix. Braz. J. Med. Biol. Res., 2003. 36(8): p. 1037-46.

18. Du, Y., et al., Multipotent stem cells in human corneal stroma. Stem Cells., 2005. 23(9): p. 1266-75.

19. Takacs, L., et al., Stem cells of the adult cornea: from cytometric markers to therapeutic applications. Cytometry A., 2009. 75(1): p. 54-66.

20. Vereb, Z., et al., Role of Human Corneal Stroma-Derived Mesenchymal-Like Stem Cells in Corneal Immunity and Wound Healing. Sci. Rep., 2016. 6: p. 26227.

21. Weller, R.O. and F.C. Rodger, Crystalline stromal dystrophy: histochemistry and ultrastructure of the cornea. Br. J. Ophthalmol., 1980. 64(1): p. 46-52.

22. Weiss, J.S., Schnyder corneal dystrophy. Curr. Opin. Ophthalmol., 2009. 20(4): p. 292-8.

23. Woreta, F.A., G.W. Davis, and K.S. Bower, LASIK and surface ablation in corneal dystrophies. Surv. Ophthalmol., 2015. 60(2): p. 115-22. 
24. Hariri, M., et al., Biogenesis of multilamellar bodies via autophagy. Mol. Biol. Cell., 2000. 11(1): p. 255-68.

25. Kaarniranta, K., et al., Autophagy and heterophagy dysregulation leads to retinal pigment epithelium dysfunction and development of age-related macular degeneration. Autophagy, 2013. 9(7): p. 973-84.

26. Albert, R., et al., Cultivation and characterization of cornea limbal epithelial stem cells on lens capsule in animal material-free medium. PLoS One, 2012. 7(10): p. e47187.

27. Levis, H.J., et al., Plastic compressed collagen constructs for ocular cell culture and transplantation: a new and improved technique of confined fluid loss. Curr Eye Res, 2013. 38(1): p. 41-52.

28. McIntosh Ambrose, W., et al., Collagen Vitrigel membranes for the in vitro reconstruction of separate corneal epithelial, stromal, and endothelial cell layers. $\mathrm{J}$ Biomed Mater Res B Appl Biomater, 2009. 90(2): p. 818-31.

29. Mi, S., et al., Ex vivo construction of an artificial ocular surface by combination of corneal limbal epithelial cells and a compressed collagen scaffold containing keratocytes. Tissue Eng Part A, 2010. 16(6): p. 2091-100.

30. Chaloin-Dufau, C., et al., Identification of keratins 3 and 12 in corneal epithelium of vertebrates. Epithelial Cell Biol, 1993. 2(3): p. 120-5.

31. Merjava, S., et al., Cytokeratin 8 is expressed in human corneoconjunctival epithelium, particularly in limbal epithelial cells. Invest Ophthalmol Vis Sci, 2011. 52(2): p. 787-94.

32. Joseph, A., et al., Epithelial cell characteristics of cultured human limbal explants. $\mathrm{Br}$ J Ophthalmol, 2004. 88(3): p. 393-8.

33. Ghoubay-Benallaoua, D., et al., Human epithelial cell cultures from superficial limbal explants. Mol Vis, 2011. 17: p. 341-54.

34. Kurpakus, M.A., M.T. Maniaci, and M. Esco, Expression of keratins K12, K4 and K14 during development of ocular surface epithelium. Curr Eye Res, 1994. 13(11): p. 805-14.

35. Chen, Z., et al., Characterization of putative stem cell phenotype in human limbal epithelia. Stem Cells, 2004. 22(3): p. 355-66.

36. Kim, M., et al., The multidrug resistance transporter ABCG2 (breast cancer resistance protein 1) effluxes Hoechst 33342 and is overexpressed in hematopoietic stem cells. Clin Cancer Res, 2002. 8(1): p. 22-8.

37. Bhattacharya, S., et al., Maintenance of retinal stem cells by Abcg2 is regulated by notch signaling. J Cell Sci, 2007. 120(Pt 15): p. 2652-62.

38. Priya, C.G., et al., Identification of human corneal epithelial stem cells on the basis of high ABCG2 expression combined with a large N/C ratio. Microsc Res Tech, 2013. 76(3): p. 242-8.

39. Nubile, M., et al., Pathological changes of the anatomical structure and markers of the limbal stem cell niche due to inflammation. Mol Vis, 2013. 19: p. 516-25.

40. $\quad$ Figueira, E.C., et al., The phenotype of limbal epithelial stem cells. Invest Ophthalmol Vis Sci, 2007. 48(1): p. 144-56.

41. Merjava, S., et al., The spectrum of cytokeratins expressed in the adult human cornea, limbus and perilimbal conjunctiva. Histol Histopathol, 2011. 26(3): p. 323-31.

42. Michel, M., et al., Keratin 19 as a biochemical marker of skin stem cells in vivo and in vitro: keratin 19 expressing cells are differentially localized in function of anatomic sites, and their number varies with donor age and culture stage. J Cell Sci, 1996. 109 (Pt 5): p. 1017-28. 
43. Donisi, P.M., et al., Analysis of limbal stem cell deficiency by corneal impression cytology. Cornea, 2003. 22(6): p. 533-8.

44. Ramos, T., D. Scott, and S. Ahmad, An Update on Ocular Surface Epithelial Stem Cells: Cornea and Conjunctiva. Stem Cells Int, 2015. 2015: p. 601731.

45. Sacchetti, M., et al., Clinical and cytological findings in limbal stem cell deficiency. Graefes Arch Clin Exp Ophthalmol, 2005. 243(9): p. 870-6.

46. Hernandez Galindo, E.E., et al., Expression of Delta Np63 in response to phorbol ester in human limbal epithelial cells expanded on intact human amniotic membrane. Invest Ophthalmol Vis Sci, 2003. 44(7): p. 2959-65.

47. Rama, P., et al., Limbal stem-cell therapy and long-term corneal regeneration. N Engl J Med, 2010. 363(2): p. 147-55.

48. Huang, M., et al., Roles of limbal microvascular net and limbal stroma in regulating maintenance of limbal epithelial stem cells. Cell Tissue Res, 2014.

49. Utheim, T.P., et al., Comparison of the histology, gene expression profile, and phenotype of cultured human limbal epithelial cells from different limbal regions. Invest Ophthalmol Vis Sci, 2009. 50(11): p. 5165-72.

50. Oldenborg, P.A., CD47: A Cell Surface Glycoprotein Which Regulates Multiple Functions of Hematopoietic Cells in Health and Disease. ISRN Hematol, 2013. 2013: p. 614619.

51. McCracken, M.N., A.C. Cha, and I.L. Weissman, Molecular Pathways: Activating T Cells After Cancer Cell Phagocytosis from Blockade of CD47 "Don't Eat Me" Signals. Clin Cancer Res, 2015.

52. Lv, Z., et al., Loss of Cell Surface CD47 Clustering Formation and Binding Avidity to SIRPalpha Facilitate Apoptotic Cell Clearance by Macrophages. J Immunol, 2015.

53. Kisselbach, L., et al., CD90 Expression on human primary cells and elimination of contaminating fibroblasts from cell cultures. Cytotechnology, 2009. 59(1): p. 31-44.

54. Moraes, D.A., et al., A reduction in CD90 (THY-1) expression results in increased differentiation of mesenchymal stromal cells. Stem Cell Res Ther, 2016. 7(1): p. 97.

55. Nagymihaly, R., et al., Effect of Isolation Technique and Location on the Phenotype of Human Corneal Stroma-Derived Cells. Stem Cells Int, 2017. 2017: p. 9275248.

56. Thill, M., et al., A novel population of repair cells identified in the stroma of the human cornea. Stem Cells Dev, 2007. 16(5): p. 733-45.

57. Chen, S., M.J. Mienaltowski, and D.E. Birk, Regulation of corneal stroma extracellular matrix assembly. Exp Eye Res, 2015. 133: p. 69-80.

58. Massoudi, D., F. Malecaze, and S.D. Galiacy, Collagens and proteoglycans of the cornea: importance in transparency and visual disorders. Cell Tissue Res, 2015. 363(2): p. 337-49.

59. Meek, K.M. and C. Boote, The organization of collagen in the corneal stroma. Exp Eye Res, 2004. 78(3): p. 503-12.

60. Meek, K.M. and N.J. Fullwood, Corneal and scleral collagens--a microscopist's perspective. Micron, 2001. 32(3): p. 261-72.

61. Meek, K.M. and C. Knupp, Corneal structure and transparency. Prog Retin Eye Res, 2015. 49: p. 1-16.

62. Wu, J., et al., Corneal stromal stem cells versus corneal fibroblasts in generating structurally appropriate corneal stromal tissue. Exp. Eye Res., 2014. 120: p. 71-81.

63. Lajoie, P., et al., The lipid composition of autophagic vacuoles regulates expression of multilamellar bodies. J. Cell Sci., 2005. 118(Pt 9): p. 1991-2003.

64. Petrovski, G., et al., Autophagy in the eye: a double-edged sword, N. Gorbunov, Editor. 2012, Nova Science Publishers: Hauppauge, New York. p. 157-180. 
65. Frost, L.S., C.H. Mitchell, and K. Boesze-Battaglia, Autophagy in the eye: implications for ocular cell health. Exp. Eye Res., 2014. 124: p. 56-66.

66. Choi, S.I., et al., Impaired autophagy and delayed autophagic clearance of transforming growth factor beta-induced protein (TGFBI) in granular corneal dystrophy type 2. Autophagy, 2012. 8(12): p. 1782-97.

67. Choi, S.I. and E.K. Kim, Autophagy in granular corneal dystrophy type 2. Exp Eye Res, 2015. 144: p. 14-21.

68. Hassell, J.R. and D.E. Birk, The molecular basis of corneal transparency. Exp Eye Res, 2010. 91(3): p. 326-35.

69. Weiss, J.S., Schnyder corneal dystrophy. Curr Opin Ophthalmol, 2009. 20(4): p. 2928.

70. Orr, A., et al., Mutations in the UBIAD1 gene, encoding a potential prenyltransferase, are causal for Schnyder crystalline corneal dystrophy. PLoS One, 2007. 2(8): p. e685.

71. Weiss, J.S., et al., Mutations in the UBIAD1 gene on chromosome short arm 1, region 36, cause Schnyder crystalline corneal dystrophy. Invest Ophthalmol Vis Sci, 2007. 48(11): p. 5007-12.

72. Klintworth, G.K., Corneal dystrophies. Orphanet J Rare Dis, 2009. 4: p. 7. 